\title{
CITIES INSIDE OUT: RACE, POVERTY, AND EXCLUSION AT THE URBAN FRINGE
}

\section{Michelle Wilde Anderson ${ }^{*}$}

\begin{abstract}
Are county governments capable stewards of urban life? Across the country, millions of low-income households live in urban enclaves that rely on county government for their most proximate tier of general purpose local government. Material conditions in many of these neighborhoods are reminiscent of early twentieth-century rural poverty, while others are a dystopic vision of twenty-first century urbanity, with clusters of housing tucked in between landfills, industrial plants, and freeways. This Article provides a vocabulary and a conceptual baseline for understanding this national pattern of unincorporated urban areas and presents a qualitative study of these neighborhoods in California, Texas, Florida, and North Carolina. It explores the governmental status of these communities, and asks, for the first time, whether two tiers of general purpose local government-a city and a county - offer urbanized areas greater participatory voice, stronger protection from undesirable land uses, improved collective services, and greater housing choice than county rule alone. Providing a framework for evaluating local government, this Article posits that housing-market mobility, neighborhood habitability, and political voice are the three pillars of adequate local government. By this metric, we can no longer assume that county governments are equivalent to municipalities.
\end{abstract}

INTRODUCTION

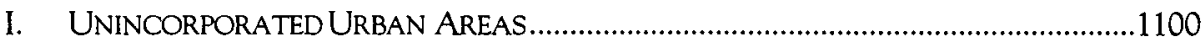

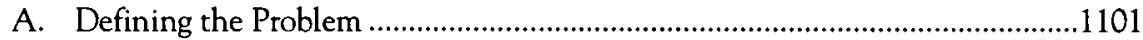

B. Unincorporated Urban America.....................................................................1106

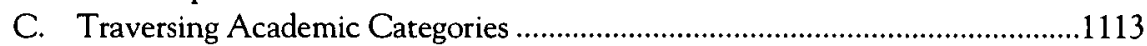

1. Municipal Underbounding .....................................................................1113

2. Related Patterns: Colonias and Black Rural Poverty ..............................1115

* Environmental Law Fellow, Shute, Mihaly \& Weinberger LLP. I am grateful to The Chief Justice Earl Warren Institute for Race, Ethnicity, and Diversity at Boalt Hall School of Law for providing me with a writing fellowship to undertake this project. Further thanks go to Kathy Abrams, Suzanne Borghei, Guido Calabresi, Juan Carlos Cancino, Phil Frickey, Gerald Frug, Tim Iglesias, Sonya Lebsack, Jennifer Mnookin, Andrea Peterson, Joe Singer, Kirk Stark, David Super, and the attorneys of Shute, Mihaly \& Weinberger, LLP for their thoughtful comments on this Article and their support of this research. A wide range of interviewees supported this project with their time and knowledge. Above all, this Article is the culmination of Ian Haney Lopez's tireless mentorship and Sade Borghei's unbending confidence. 
D. Beyond White Flight: Looking Towards the Low-Income Periphery.

II. ORIGINS, PERSISTENCE, AND PERPETUATION

A. The History of Unincorporated Urban Areas

B. An Economic Gravity Pattern of Urban Development....

III. URBAN LIFE WITHOUT URBAN GOVERNMENT

A. A Model for Evaluating Local Government Adequacy

B. Adequacy Applied: Single-Tier Local Government

1. A Few Words About County Government.

2. Mobility: The Right to Move, the Right to Stay

3. Habitability: Safety, Services, and Clean Neighbors

4. Political Voice: County Democracy

CONCLUSION

\section{INTRODUCTION}

The flight of wealth from central municipalities was the twentieth century's indelible mark on America's urban history. Local government law as an academic field developed amidst this exodus to the suburbs. As a result, it has focused on questions of municipal incorporation, annexation, regional governance, and voting rights through the lens of the polarizing economic and racial characteristics of core cities and their suburbs. Taking nothing away from the powerful history written by that scholarship, the centrality of this model of urban change has diverted our attention away from nonconforming histories and places. In these understudied contexts, millions of low-income families live outside central cities on pockets of unincorporated land and in economically marginal suburban or rural municipalities. Viewing this wider and more complex picture turns our notions about cities inside out, exposing fringes where low wages, the need for affordable housing, and the aspiration for family-friendly suburban life have pushed low-income communities beyond the limits of central cities. This Article follows that migration, moving past the traditional paradigm of "cities" and "suburbs" to discover narratives of hardship, adaptation, diversity, and accomplishment among low-income suburban pioneers and their successors. It takes a step in advancing this underdeveloped line of legal scholarship by naming and defining the problem of unincorporated urban areas, a heretofore largely unnoticed pattern of low-income suburbanization.

Two places introduce us to this new pattern. The City of Modesto, located in California's agricultural heartland of fruit and nut groves, relies economically on several industrial canneries located near city limits, and the surrounding Stanislaus County depends on the cultivation of thousands of 
acres of crops. On the other side of the country, the "bent-grass paradise" of North Carolina's Village of Pinehurst and its neighboring towns boast some of the nation's most prestigious golf facilities, fueling surrounding Moore County with hundreds of millions of dollars in golf-event revenues. At the backbone of these regional economies teem thousands of workers: agricultural laborers, seasonal cannery workers, caddies, maids, cooks, laundry staff, and groundskeepers.

Where do these workers live? Not in the bright-grass, white-picket residential areas of Modesto or in the lakeside estates of Pinehurst. They live where one might expect them to-in neighborhoods with the advantage of proximity, the necessity of affordability, and the possibility of home ownership. In these regions, such neighborhoods lie where the sidewalks, and the city borders, end. On patches of unincorporated land at the municipal fringe, low-wage workers live without water or sewage lines, sidewalks or paved roads, drainage or flood control. Health and safety risks plague local water and soil, as communities rely on rural-character services in urbanized areas built on environmentally damaged or disaster-vulnerable land.

Current residents' predecessors, often their own grandparents and great-grandparents, settled these neighborhoods fifty to one hundred years ago to achieve sustenance and independence in the face of racial segregation, wage discrimination, and poverty. Their neighborhoods remain racially obvious today: three-fourths Latino in Stanislaus County's Bret Harte neighborhood, for instance, and nearly one hundred percent African American in Moore County's Jackson Hamlet. Decade after decade, these communities have been denied or overlooked for annexation to their adjacent municipalities. Though contiguous with an incorporated town or city and integrated with that city's social and economic life, these unincorporated "islands" or urbanized clusters at the city fringe have been mapped out of municipal boundaries.

Due to crisis conditions caused by failing septic systems, civil rights advocates have launched legal efforts to pursue municipal service improvements and annexation for these marginalized communities. ${ }^{2}$ They have little

1. Wright Thompson, Wrong Side of the Tracks Midway N.C., Surrounded by Toun That Left It Behind, CHARLESTON GAZETTE, June 17, 2005, at P5C.

2. The Lawyers' Committee for Civil Rights of the San Francisco Bay Area, California Rural Legal Assistance, and Heller Ehrman LLP brought litigation to address service needs in the neighborhoods locked out of the boundaries of Modesto. The University of North Carolina Center for Civil Rights has represented the unincorporated enclaves of Moore County for more than ten years, using community organizing and political advocacy to secure neighborhood improvements. This author served on the original legal team that investigated the communities outside Modesto and explored avenues for redress. 
context for their work. Zones of urban life without urban government have been virtually invisible to the literature of law and city planning, enacting the names for two such neighborhoods, "Lost City" and "No Man's Land." Yet these communities are not alone. They represent a phenomenon that is national in scope, urgently in need of attention, and deeply rooted in our current system of local government law.

This Article fills that gap, providing a legal framework to understand the national problem of neighborhoods that I refer to as "unincorporated urban areas": low-income, urbanized areas bordering incorporated municipalities but denied or bypassed for annexation for at least twenty-five years. Communities lacking rudimentary urban services (like those in Stanislaus and Moore Counties) represent just one of two types of unincorporated urban areas. A second and often overlapping category of such places-including at least 300,000 people in eastern Los Angeles County alone-has basic services but houses a disproportionate share of undesirable facilities serving the larger metropolitan area, such as landfills, industrial complexes, sewage treatment plants, and freeways.

Unincorporated urban areas might be little different than other nodes of poverty on the urban landscape but for this: They rely on only one tier of general purpose local government, a county, while urban areas within municipalities rely on both a city and a county. Does this distinction make a difference? This Article explores that question, asking whether county governments are different than municipal governments in ways that explain the histories of unincorporated urban areas and the challenges they face. To differentiate cities and counties in terms of their capacity to provide for urbanized populations, I provide a framework for evaluating local government-a way of analyzing whether people have enough local government or the right kind of local government.

Synthesizing insights from fair housing and voting rights law, public choice theory, and political theory, I set the normative perspective underlying this evaluation (the orientation point for determining what makes a local government sufficient or suitable) to be a local government's capacity and performance at pursuing three values: choice on the housing market (mobility), protection from undesirable land uses and the provision of collective services (habitability), and access to participatory democracy (political voice). Applied to unincorporated urban areas, this theoretical model helps both to explain the relative stasis in these communities over time and to identify the conditions necessary for corrective progress. County governments are not oversized equivalents of municipal governments; they are significantly 
distinct in ways that affect land values, material conditions, and political accountability. Counties' increasing role in governing urbanized populations will become, I argue, a central element of America's twenty-first century urban condition.

Part I presents the first national study of unincorporated urban areas, providing a vocabulary, definitional framework, and qualitative foundation for understanding the issue. Locating the unincorporated urban areas classification in the existing literature, I identify the shared ground between black rural poverty and colonias communities, two urban development patterns previously understood as unrelated, racially compartmentalized, and regionally specific. In Part II, the Article moves to underlying dynamics, looking beyond the Big Bang model of postwar white flight to recognize historic and current manifestations of what I call an economic gravity model of urban development, in which exclusionary zoning interacts with cities' magnetic pull on wage earners to generate unregulated, peripheral development for low-income families. The resulting communities exhibit the curious state of urban life under county rule. Part III places county government in high relief, providing an analytical framework for evaluating local governments and applying that framework to counties.

By virtue of the relatively unchartered terrain explored in this Article and the need to establish a baseline from which to organize future research, I employ three methodologies and disciplinary perspectives. First, I define the nature and scope of the problem of unincorporated urban areas using qualitative empirical research. To unravel the origins of these neighborhoods and their persistence over time, I pair historical inquiry and urban planning theory. Finally, I draw upon local government political theory, with special attention to the economic and political incentives of municipalities and the residents of unincorporated urban areas, to assess the legal dynamics underlying the problem.

Cities Inside Out represents the first in a series of articles investigating unincorporated urban areas and providing a new legal framework for understanding communities that fall outside the white flight model of urban change. This first Article analyzes the origins and governance of these communities, theorizing the role of county government in shaping unincorporated urban areas. Mapped Out of Local Democracy, ${ }^{3}$ a forthcoming piece, takes a prescriptive turn, exploring roads to reform located in civil rights law, market-based self-correction, and state and local government law.

3. Michelle Wilde Anderson, Mapped Out of Local Democracy (Apr. 7, 2008) (unpublished manuscript, on file with author). 
Regional Localism: American County Government, ${ }^{4}$ also forthcoming, deepens and complicates our understanding of the legal context, constraints, and opportunities of county government, providing typologies to capture the range of American counties.

The social justice problem at the heart of the unincorporated urban areas pattern is clear: In a number of high-poverty, unincorporated neighborhoods, urban labor forces struggle to balance low wages with a dangerous and degrading absence of public investment in the physical state and safety of their neighborhoods. At this urban periphery, with its landscapes of privation and perseverance, we find a new frontier in the quest for distributive justice in the context of the opportunities and vulnerabilities attached to land.

\section{UNINCORPORATED URBAN AREAS}

On a strip of county land stranded between Austin, Texas and the neighboring city of Round Rock nests a small, low-income community of about 350 residents known as Northridge Acres. The neighborhood lacks access to safe, reliable water, and many blocks are plagued by drainage problems and failing septic systems that "mak[e] flushing during a rainstorm a potential health hazard." Residents of Northridge Acres pay more than double what Austin residents pay for water, even though their supply is severely limited and often contaminated by human waste. ${ }^{6}$

This Part investigates the problem of communities like Northridge Acres, establishing a vocabulary for understanding their common characteristics and providing preliminary research about the scope and nature of the phenomenon. It explores the relationship of the unincorporated urban areas classification to municipal underbounding, colonias development, and black rural poverty - three existing academic categories that heretofore have been treated independently but in fact are deeply related to one another and partially coincident with the phenomenon of unincorporated urban areas. Presenting a broader understanding of dynamics at the urban fringe, this Part calls for sustained academic engagement with low-income suburbs.

4. Michelle Wilde Anderson, Regional Localism: American County Government (Apr. 7, 2008) (unpublished manuscript, on file with author).

5. Jeff Claassen \& John Gutierrez-Mier, Faulty Water and Wastewater Facilities Take Environmental Toll, FORT WORTH STAR-TELEGRAM, Nov. 6, 2005; see also Walier Howerton, Jr., Between Round Rock and a Hard Place: Tiny Northridge Acres Is a Colonia on the Border-of Austin, THE AUSTIN CHRON., Nov. 15, 2002.

6. See Howerton, supra note 5. 


\section{A. Defining the Problem}

Unincorporated urban areas, as I define them, include neighborhoods that are: (1) unincorporated (lying outside the borders of any incorporated city $\left.^{7}\right) ;(2)$ contiguous on one or more sides with a municipal border or lying within the area legally designated for a city's expected growth (denoted in some states as a sphere of influence or extraterritorial zoning jurisdiction); (3) primarily residential, with densities greater than or similar to adjacent incorporated land; ${ }^{8}$ and (4) low-income, as defined by census tract data. ${ }^{9}$ I limit my use of this term to communities that have been in existence for more than twenty-five years in order to exclude those neighborhoods that may simply be in transition, awaiting natural absorption by their adjacent municipality.

This definition is notably race-neutral. I did not limit the communities studied according to racial criteria, thus presuming that the pattern of underserved or overburdened poverty at the unincorporated urban fringe would be associated with particular racial groups. Yet strikingly, every community I found that qualified as an unincorporated urban area was predominantly African American or Latino. ${ }^{10}$ Indeed, each community uncovered by my research traced its origins to laws or norms enforcing racial segregation. As a result, I understand the pattern of unincorporated urban areas to derive in part from racial discrimination.

With great consistency, unincorporated urban areas fall into one or both of two categories. One group lacks one or more vital service, such as piped, potable water; sewage and wastewater disposal; adequate law enforcement and fire protection; street paving, lighting, and traffic control; and/or flood and stormwater control. A second, often overlapping group faces health risks and depressed land values due to a concentration of a metropolitan

7. I use the word "city" in a political sense-to denote the political unit of an incorporated municipality, regardless of size or urbanity. Under this definition, an incorporated municipality functioning as a residential suburb qualifies as a city, as would a small incorporated town.

8. The second and third prongs of this definition reflect my expansive usage of the term "urban," which I use to encompass spaces, with or without any nonresidential uses, that at minimum (1) include a cluster of residences at what are commonly thought of as either "urban" or "suburban" residential densities, and (2) are located near the border of an incorporated municipality, whether town, city, or suburb. This definition distinguishes "urban" spaces from sparsely populated, scattered farms and settlements that are isolated from a municipality.

9. I have chosen the term "unincorporated urban areas" because, though impersonal, it offers the compelling advantages of being normatively, regionally, and racially neutral, while also providing descriptive specificity. This term, however, is not quite complete. It is shorthand for "low-income unincorporated urban areas," as distinct from unincorporated neighborhoods near city borders that are middle or upper income. This latter type of unincorporated urban area is discussed in Part III.B.

10. Comprehensive statewide mapping could, however, reveal similar predominantly white communities, particularly in states with large concentrations of white rural poverty. 
area's undesirable land uses, contamination from past land uses, or uncontrolled vulnerability to natural disaster. The first category of unincorporated urban areas has not been properly understood as a nationwide pattern. The second category has been misunderstood - efforts to address the poverty, crime, and environmental justice issues in these areas overlook their unincorporated status, a structural dimension of their decline and disenfranchisement.

How many such communities are there? This Article, with its focus on questions of local government law and urban development, does not undertake a quantitative investigation of unincorporated urban areas, beyond a brief discussion of existing empirical studies. Instead, I have used qualitative methods to locate dozens of communities meeting this Article's definition of unincorporated urban areas. " Case studies and the observable patterns among them frame the legal issues discussed here and provide a framework for a comprehensive, multiyear quantitative analysis of unincorporated urban areas that is currently in the planning stages. ${ }^{12}$

The research underlying the present Article focused on unincorporated urban areas within four pilot states-California, Texas, Florida, and North Carolina. ${ }^{13}$ These states were selected because, first, they represent a cross-section of regional geographies, encompassing the United States-Mexico border, the South, and the West. They also represent diverse land-use regimes (ranging from Texas's more libertarian scheme to California's highly

11. The study underlying the present Article involved qualitative research on a series of case studies. I located the group of unincorporated urban areas for study through research in local newspapers, interviews with advocates for low-income communities, internet research, interviews with historians and geographers, census tract data analysis, and review of county-wide maps. The study targeted two to six counties in each state, and each county included a range of one to seven unincorporated urban areas. Research on each unincorporated urban area included interviews with residents; media searches and interviews with local journalists; demographic analysis on rates of poverty, race, and homeownership; interviews with local government officials; windshield surveys (California only); and, where available, local historical research. At the state level, I researched the legal rules governing annexation, local government extraterritorial authority, county taxation authority, and local government structure.

12. In collaboration with the Chief Justice Earl Warren Institute on Race, Ethnicity, and Diversity at Boalt Hall School of Law, the University of North Carolina Center for Civil Rights, and the Southern Coalition for Social Justice, I will undertake such an investigation in 2008-2010.

13. Initial research also included Ohio, which has several communities that satisfy the definition of unincorporated urban areas. However, the state's local government system, which subdivides counties into townships that enjoy a core set of land-use and other regulatory powers, substantially distinguishes Ohio from the other states of study in terms of county power, interlocal relations between municipalities and counties, and governance within the state's unincorporated areas. Though the unincorporated urban areas of Ohio are occasionally referenced in Parts I and II of this Article in order to better understand the manifestations of this issue nationally, these communities are excluded from Part llI's analysis of county government. 
regulated context ${ }^{14}$ ), annexation laws (including North Carolina's so-called progressive annexation laws, which permit cities to annex peripheral areas against their will, and California's centralization of annexation approvals through a state agency ${ }^{15}$ ), and local government structures (including Florida's countyled efforts to support city-county consolidations and the municipal annexation of all unincorporated land remaining within certain conurbations ${ }^{16}$ ). And finally, unincorporated urban areas within these states were first settled during diverse historical settings, including the post-Emancipation South, the Great Migration of the early twentieth century, and the midcentury agricultural and industrial expansion of the West and the United States-Mexico border states. Such multifaceted diversity suggests that the unincorporated urban areas phenomenon is in fact national in scope, rather than an idiosyncrasy of one region, one type of state legal regime, or one racial community's local history. ${ }^{17}$ It provides a broad foundation for observation of unifying development patterns and underlying legal dynamics.

14. For an excellent discussion of Texas's comparatively unregulated county land-use regimes, see Jane E. Larson, Free Markets Deep in the Heart of Texas, 84 GEO. L.J. 179 (1995). For a discussion of California's regime, where the state has granted extensive land-use planning authority to its local governments, see DANIEL J. CURTIN, JR. \& CECILY T. TALBERT, CURTIN'S CALIFORNIA LAND USE AND PLANNING LAW 103-09 (2008) (describing local authority to impose a wide range of substantive development conditions on subdivisions).

15. North Carolina state law authorizes municipalities to expand their boundaries without a vote by affected residents, a practice known as "involuntary annexation" that is permissible in a small minority of states. See N.C. GEN. STAT. \& 160A-49 (2005). See generally Elizabeth R. Connolly, Bargain Basement Annexation: How Municipalities Subvert the Intent of North Carolina Annexation Laws, 29 N.C. CENT. L.J. 77 (2006); Karen Ubell, Recent Development, Consent Not Required: Municipal Annexation in North Carolina, 83 N.C. L. REV. 1634 (2005). For an analysis of the significance of involuntary annexation powers, see Laurie Reynolds, Rethinking Municipal Annexation Powers, 24 URB. LAW. 247 (1992). California has established specialized Local Agency Formation Commissions, state agencies that oversee annexations and broker city-county relationships concerning growth. See CAL. GOVT. CODE $\$ \S 56300-56301,56375$ (2008). See generally Cortese-Knox-Hertzberg Local Government Reorganization Act of 2000, CAL. GOVT. \$56000-57550. For a comprehensive analysis of the level of democratic input in annexation decisions, which are subject to a diversity of procedural rules, see Clayton P. Gillette, Voting With Your Hands: Direct Democracy in Annexation, 78 S. CAL. L. REV. 835 (2005).

16. Florida has seen the aggressive pursuit (albeit usually unsuccessful) of city-county consolidations and other means of eliminating unincorporated land. Voters in six counties in the state have considered full or partial consolidation one or more times, and such measures were successful in the City of Jacksonville in Duval County and the City of Miami in Dade County. See Chris Briem, Some Major City-County Consolidation Referenda in the 20th Century, http://www.briem.com/frag/CityCountyReferenda.htm (last visited May 15, 2008). Broward County has actively sought and promoted the annexation of its few remaining unincorporated areas by its constituent municipalities. See infra note 59.

17. However, there are a small minority of states, regions, and cities where the unincorporated urban areas issue by definition will not arise. These include consolidated city-county governments (like San Francisco, Denver, and Honolulu); "independent" cities not included within any county's territory (such as Baltimore City, St. Louis City, and 39 cities in Virginia); areas in 
Although heretofore unidentified as a unified pattern, several empirical studies of the South and the United States-Mexico border provide piecemeal data suggestive of the scale of the unincorporated urban areas problem. A recent study of census data from 1990 and 2000 by Daniel Lichter and other geographers, for instance, found strong indications that African American communities adjacent to nonmetropolitan towns in the South are more likely to be bypassed for annexation than similar white communities. ${ }^{18}$ Moreover, it concluded that southern towns were less likely to annex any land at the periphery at all, whether majority black or white, where the unincorporated periphery eligible for annexation included a large black population-even where available socioeconomic controls were introduced to distill the effects of race rather than class-based exclusion. ${ }^{19}$

The Lichter study found that annexation was also less likely where largely white towns faced a so-called black threat, defined as towns in which the percentage of black residents in the county was higher than the percentage of black residents in the town. ${ }^{20}$ Towns with predominantly white populations were much less likely to annex black unincorporated areas, even with statistical controls on the size of the black fringe population. ${ }^{21}$ These findings are all the more striking given that where the racial population of the municipality itself was not taken into account, the study revealed a less substantial discrepancy between black populations defined as "at risk" for annexation and those actually annexed. In other words, it was predominantly white towns, not predominantly black ones, that exhibited patterns of exclusion. ${ }^{22}$ The study found evidence, though it could not

which one or more county governments has been subsumed within a city government and all land is incorporated within that city (like New York City, Jacksonville, and Indianapolis); and states with county designations, but in which all territory lies within a municipality and there is no functioning unit of county government (as in Rhode Island, Connecticut, and most of Massachusetts). See U.S. CENSUS BUREAU, 2002 CENSUS OF GOVERNMENTS: GOVERNMENT ORGANIZATION (2002), at app. B, available at http://www.census.gov/govs/www/cog2002.html.

18. The study covered the area of the "Old South," defined to include Virginia, North Carolina, South Carolina, Georgia, Alabama, Mississippi, Louisiana, and Arkansas. It relied on GIS, Tiger files, and other geographically disaggregated data from the 1990 and 2000 censuses to investigate the racial composition of small-town fringe populations in the South that were annexed or not annexed between 1990 and 2000, as well as to identify factors associated with racially selective annexation. See Daniel T. Lichter et al., Municipal Underbounding: Annexation and Racial Exclusion in Small Southern Towns, 72 RURAL SOC. 47, 48, 51 (2007).

19. Id. at 63,66 .

20. Id. at 47 .

21. Id. at $63-65$.

22. Id. at 66-67. African Americans made up 22.6 percent of the fringe areas defined as "at risk" for annexation, as compared to African Americans' slightly lower 20.7 percent representation in the areas actually annexed during the 1990s. 
draw final conclusions on the point, that exclusion of these areas was motivated by race rather than class. ${ }^{23}$

An older regional study of the fifty-seven municipalities within the Yazoo Delta of Mississippi similarly found evidence of housing patterns and annexations affected by race. ${ }^{24}$ The study determined that 20 percent of the region's black population lived within one mile (but outside the borders) of a municipality, and more than 90 percent of the municipalities with a large fringe population (at least one-half the size of the municipality's population) had a larger black population in their fringe than in the municipality. ${ }^{25}$ This means that many African American households in the region lived in the urban fringe outside town lines, and municipalities that had failed to annex a populous urban fringe had more African Americans living outside municipal lines than within them.

The proliferation of colonias housing at the United States-Mexico border provides a further glimpse of the scale of the unincorporated urban areas pattern. Colonias, which are discussed in detail in Part I.B below, are commonly defined as low-income subdivisions that are lacking in basic infrastructure. ${ }^{26}$ Within the border region of Texas alone, scholars estimate that 350,000 people live in settlements satisfying the federal definition of colonias; ${ }^{27}$ in New Mexico there are 42,000 such residents. ${ }^{28}$ Recent research has identified 1,800 colonias in Texas, 138 in New Mexico, 32 in California, and 77 in Arizona. ${ }^{29}$ The Texas Water Development Board estimates that 1.2 million Texans need water and wastewater system improvements that would cost more than $\$ 4.5$ billion. ${ }^{30}$ In the eight counties of California's San Joaquin Valley, the heart of the state's agricultural industry, researchers have

23. See id,; see also Daniel T. Lichter et al., National Estimates of Racial Segregation in Rural and Small-Toum America, 44 DEMOGRAPHY 563, 581 (2007) (finding that levels of racial segregation are heightened by the exclusion of African American neighborhoods by small Southern towns).

24. See Charles S. Aiken, Race as a Factor in Municipal Underbounding, 77 ANNALS ASS'N AM. GEOGRAPHERS 564 (1987).

25. Id.

26. See, e.g., Jane E. Larson, Informality, Illegality, and Inequality, 20 YALE L. \& POL'Y REV. $137,140(2002)$.

27. PETER M. WARD, COLONIAS AND PUBLIC POliCY IN TEXAS AND MEXICO: URbanization BY STEALTH 1 (1999).

28. Chad K. Wakefield, Colonias Along the United States/Mexico Border: The Issue and Impact of Colonias in Southern New Mexico, Paper presented at the American Planning Association 2001 National Planning Conference (March 14, 2001) (transcript available at http://www.design.asu.edu/ apa/proceedings $01 /$ contents.htm).

29. Vinit Mukhija \& Paavo Monkkonen, What's in a Name? A Critique of Colonias in the United States, 31 INT'L J. URB. \& REgional Res. 475, 476 (2007).

30. Jake Bernstein, Don't Drink the Water: In the Urban Colonias of the Greater Houston Area, the Water Stinks, THE TEXAS OBSERVER, Dec. 2, 2005. 
found 219 low-income, unincorporated communities. ${ }^{31}$ These numbers provide only a starting point for estimating the number of unincorporated urban areas, however, because, as discussed in Part I.C, not all colonias communities are located near or on a city's border, and not all unincorporated urban areas qualify as colonias.

The communities identified by my own qualitative analysis came to public light only after symptoms of distress became acute-an unincorporated subdivision's septic tanks aging and failing; a Latino mayoral candidate in a city election speaking out because decisive blocks of his putative supporters live just outside city borders; a proposed freeway route threatening to demolish sections of a community founded soon after Emancipation. Yet the nature of the unincorporated urban areas pattern suggests that the communities to have surfaced thus far are only examples of a more widespread pattern. Unincorporated urban areas tend to be small pockets with weak political and economic capital, and advocacy efforts by residents to obtain an equitable share of public investment have been quiet, flying under the radar of most journalists, political leaders, and academics. Ida Mae Murchison, a resident of an unincorporated urban area in North Carolina and a housekeeper in the adjacent city for nearly fifty years, captured this invisibility and reticence. "I get the feeling that we're just forgotten, put on the shelf or the back burner or something," she said. But she hesitated, emphasizing that she did not seek "to offend anyone" or "cause trouble."

To find unincorporated urban areas, geographers, policymakers, and civil rights advocates simply need to look for them.

\section{B. Unincorporated Urban America}

Clean water, sewage disposal, law enforcement, protection from land hazards, and a sound economic base are five of the basic conditions of residential quality of life and the appreciation of land values. Each of these attributes is, to one extent or another, beyond a homeowner's control. None can be taken for granted in unincorporated urban areas.

One need not travel to Mexico City or Lagos for a case study on the need for clean water. In the neighborhoods of North Houston and Fresno-located outside Houston "in inconvenient corners between suburban

31. See Victor Rubin et al., Unincorporated Communities in the San Joaquin Valley: New Responses to Poverty, Inequity, and A System of Unresponsive Governance (Nov. 27, 2007) (unpublished report on file with author).

32. Shaila Dewan, Manicured Greens and Raw Sewage, THE NEw YORK TIMES, June 16, 2005 , at A19. 
boomtowns"-households on small lots rely on wells in combination with failing septic tanks, creating "disastrous" conditions of septic tank overflow during Houston's heavy rains. ${ }^{33}$ Well water that used to be potable is increasingly dirty and foul smelling, and trichlorethylene, a chemical linked with cardiac abnormalities and childhood leukemia, has been found at dangerous concentrations in wells at the nearby site of a former industrial plant. $^{34}$ Some local families spend scarce income every month on bottled water, while others, in the words of the communities' state representative Kevin Bailey, "are literally drinking their own sewage." fire hydrants means greater risk of fire and no possibility of acquiring insurance. After fifteen years of broken promises from local governments, and nearly a decade after residents voted to tax themselves to create a special water district, nothing has changed. ${ }^{36}$ Residents fear that their special district funds are supporting clean water services in new, neighboring subdivisions with artificial lakes and green lawns, where water services appeared overnight. ${ }^{37}$ Similar stories can be heard in the unincorporated urban areas outside Austin, Texas; Exeter, California; and Zanesville, Ohio, among others.

Where there is tainted water, inadequate wastewater disposal is rarely absent. Just beyond the city limits of Mebane in Alamance and Orange Counties, North Carolina, for instance, are five communities founded by former slaves shortly after the Civil War that remain 85 percent to 95 percent African American. ${ }^{38}$ Failing septic systems dogged by small lots and incompatible soil have contaminated local well water, becoming a significant health threat. ${ }^{39}$ Local authorities have refused to grant permits for the replacement systems needed by some households, which are then faced with the choice of continuing to rely on hazardous systems, reverting to an outhouse, or abandoning their parcel..$^{40}$ Each community is within blocks of Mebane sewer and water lines; the Buckhorn/Perry Hill neighborhood, for instance, is across the street from a forty-one acre

33. Bernstein, supra note 30.

34. Id.

35. Id.

36. Id.

37. Id.

38. See James H. Johnson, Jr. et al., Racial Apartheid in a Small North Carolina Town, 31 ReV. BLACK POL. ECON. 89, 94 fig.2 (2003); West End Revitalization Association, http:/www.weranc.org (last visited Mar. 31, 2008).

39. See Johnson et al., supra note 38 , at $97-98$.

40. See id. 
truck stop plaza with water and sewer services. ${ }^{41}$ Cities like Mebane generally can and often do sell water and sewer services across city lines, but charges for extraterritorial services come at a premium, and the city or county must first equip an unincorporated community with underground infrastructure to carry the services. ${ }^{42}$ Unincorporated urban areas similarly facing dangerous conditions in sewage disposal can be found in Cumberland, Union, Bertie, Hoke and Moore Counties, North Carolina; Fresno, Madera, and Stanislaus Counties, California; and Harris and El Paso Counties, Texas.

On matters of law enforcement and emergency services, the challenges faced by unincorporated urban areas are of adequacy rather than of access. Law enforcement in these areas falls to county sheriffs' departments, even where deputies must travel across long gaps in their jurisdiction to reach unincorporated islands. For the more than 300,000 people living in the unincorporated interstices of Los Angeles County, ${ }^{43}$ reliance on the county sheriff may not be a disadvantage-the county's one million total unincorporated area residents, combined with its contracts to provide law enforcement to dozens of incorporated suburbs, mean that the county has a vast, well-established system for addressing urban crime. ${ }^{44}$ By contrast, county sheriffs adapted to low-density, primarily agricultural counties like Kern, Stanislaus, and Fresno counties in California have struggled to cope with the increasing levels of urban crime and gang activity concentrated in unincorporated islands and fringes of their major cities. A recent civil rights lawsuit on behalf of unincorporated urban areas at the edge of Modesto, California alleges that a combination of their urban environment and inadequate sheriff

41. WEST END REVITALIZATION ASSOCIATION, EPA ENVIRONMENTAL JUSTICE STUDY: FAILING SEPTIC SYSTEMS AND CONTAMINATED WELl WATERS: AFRICAN-AMERICAN COMMUNITIES IN MEBANE, NORTH CAROLINA (2002), http://www.wera-nc.org/News/epa/ epaej_1202.htm.

42. In a companion article, I discuss these practices at greater length, showing that this system of providing municipal services for a price generally did not arise until after the close of de jure housing segregation. See Anderson, supra note 3.

43. Locked in the gap between several large municipalities, unincorporated East Los Angeles is home to nearly 125,000 residents -96.8 percent of whom are Latino-and it encompasses nearly all of the area commonly referred to as "East L.A." Florence-Graham, an unincorporated urban area bordered by Los Angeles and Walnut Park, holds the dubious distinction of witnessing the biggest national increase in the number of homeowners spending more than 30 percent of their incomes on housing. See Janny Scott \& Randal C. Archibold, Across Nation, Housing Costs Rise as Burden, N.Y. TIMES, Oct. 3, 2006, at A1. Lennox, a predominantly Latino unincorporated urban area of 30,000 residents, lies in the deafening flight path of Los Angeles International Airport. Other unincorporated urban areas in Los Angeles include West Compton, East Compton, Willowbrook, Westmont, and City Terrace.

44. The same is true for unincorporated urban areas in other urban counties in California, such as Alameda and Contra Costa. 
services, along with other service deficiencies in street lighting and waste disposal, have made their communities magnets for criminal activity and illegal dumping by Modesto residents. ${ }^{45}$ Residents allege that response times by the county sheriff, as well as dispatch times by the joint agency for regional 911 calls, indicate racial discrimination against the households in the primarily Latino unincorporated urban areas. ${ }^{46}$

In addition to problems of exclusion and neglect by local services, many unincorporated urban areas are burdened by more permanent defects that endanger residents' health, depress neighborhood property values, and impose private costs on residents. These burdens take two forms: the concentration of undesirable land uses within the communities and/or long-standing damage or vulnerabilities in land condition. The first problem, the dumping of undesirable land uses on unincorporated urban areas, includes the concentration of public disamenities (for example, landfills, recycling plants, and sewage treatment plants), private disamenities (such as industrial disposal sites), public utilities (for example, water and electrical plants), and chemical and toxic processing facilities. ${ }^{47}$ Such is the fate of the unincorporated urban area of North Richmond, California, which formed an integral part of the "Black Crescent" of residential areas open to blacks employed in the City of Richmond's teeming World War II shipyards. ${ }^{48}$ Today, the North Richmond community is bounded on all sides by city land, the San Francisco Bay, and a massive oil refinery that causes severe air pollution and presents major public safety risks. The neighborhood is home to 2,310 people in one of the area's highest poverty and highest crime residential neighborhoods, as well as the

45. Complaint $\$ 37$, Comm. Concerning Cmty. Improvement v. City of Modesto (CCCI), 2007 WL 4365584 (E.D. Cal., 2007) (No. CIV-F-04-6121).

46. Expert testimony adduced during residents' litigation to improve services indicated that in addition to total delays in the response time to the "priority 1" (i.e., most serious) calls to 911, the time between these calls and the dispatch of a sheriff's unit has been significantly longer in the plaintiffs' communities than in the county as a whole, a comparator unincorporated area that is 85 percent white, or in unincorporated county islands that are more than 60 percent white. See Declaration of James H. Johnson in Support of Opposition to City of Modesto's Motion for Summary Adjudication or Partial Summary Judgment as to Police Service and Bilingual Assistance at पाI 3,10, CCCI, 2007 WL 4365584 (No. CIV-F-04-6121). The Modesto Chief of Police testified that dispatch times should be consistent across the county. See Exhibit D to Declaration of Brian P. Brosnahan in Support of Plaintiffs' Opposition to City of Modesto's Motion for Summary Adjudication or Partial Summary Judgment as to Police Service and Bilingual Assistance at 63, CCCl, 2007 WL 4365584 (No. CIV-F-04-6121).

47. For a discussion of the overconcentration of undesirable land uses in poor communities and the political movement to resist such practices, see generally LUKE W. COLE \& SHEILA R. FOSTER, FROM THE GROUND UP: ENVIRONMENTAL RACISM AND THE RISE OF THE ENVIRONMENTAL JUSTICE MOVEMENT (2001).

48. See Shirley ANn Wilson MOORE, To Place OUR DeEds: The African American COMMUNITY IN RICHMOND, CALIFORNIA 1910-1963 (2000). 
city's landfill, its recycling plant, and several brownfield sites contaminated with pesticides, lead, and petroleum hydrocarbons. ${ }^{49}$ It is a similar story for Barrett Station, Texas, an unincorporated community within Houston's extraterritorial zoning authority that has about 3,000 residents, more than 86 percent of whom are African American, ${ }^{50}$ and a history reaching back to 1840 , when the settlement was founded by the freed slave Harrisson Barrett. ${ }^{51}$ During the 1960 s and early 1970 s, two industrial waste facilities near the community received 100,000 barrels of toxic chemicals each year, warranting designation as a Superfund site. ${ }^{52}$ Resulting contamination of area groundwater and a local lake used for swimming and baptisms have been linked to unusually high rates of cancer and other severe health disorders. ${ }^{53}$

Compromised land condition-stemming from hurricane exposure, subdivision and development of a flood plain, contamination by former uses, or topographical features that impede service provision-imposes costs ranging from health hazards to increased insurance rates. Public programs funded by the U.S. Environmental Protection Agency, the U.S. Army Corps of Engineers, the U.S. Departments of Agriculture and Housing and Urban Development, and various state agencies are designed to stabilize or overcome such conditions through infrastructure investments or brownfield abatement. Public money, however, seems to be in short supply for unincorporated urban areas. The Coal Run Road neighborhood outside Zanesville, Ohio, for instance, lies atop an abandoned coal mine that infuses the water in wells and local streams with the foul smell, color, and oiliness of iron and sulfur contamination. ${ }^{54}$ More than forty years of denials by the city to serve the community with water or annex it to the local water district have forced residents to choose between

49. See United States Environmental Protection Agency, Brownfields 2005 Grant Fact Sheet: North Richmond Community Housing Development Corporation, CA, http://www.epa.gov/swerosps/ bf/05grants/northrichmondchdc.htm (last visited Mar. 30, 2008).

50. See Barrett CDP, Texas, Census 2000 Fact Sheet, http://factfinder.census.gov (type "Barrett" under "city/town" and select "Texas" under "state"; then click "Go") (last visited Mar. 30, 2008). Owner-occupancy rates in Barrett are upwards of 78 percent. See id.

51. See Carla Rabalais, Restoring an Ancestor's Dream; Barrett Station's John Barrett has a Revitalization Plan, HOUSTON CHRONICLE, June 18, 2006, at B5.

52. See Environmental Justice in Barrett Station, CLEARING THE AIR NEWSLETTER (Mothers for Clean Air), Summer 1999, http://www.mothersforcleanair.org/newsletters/1999-summer.html. Superfund is the name of an environmental program that governs and funds clean up of abandoned hazardous waste sites. Environmental Protection Agency: Superfund, http://www.epa.gov/superfund (last visited May 11, 2008).

53. See id.; H. Dayal et al., Symptom Clusters in a Community With Chronic Exposure to Chemicals in Two Superfund Sites, 50 ARCHIVES ENVTL. HEALTH 108 (1995) (attributing the high frequency of neurological symptoms in the stable black community of Bartet Station, Texas to chemical dumping at neighboring National Priority List sites).

54. See Randy Ludlow, Racism Colors Water Service, COLUMBUS DisPATCH, June 21, 2003, at 1A. 
investing in expensive wells that draw contaminated water or purchasing and hauling household water from the water treatment plant and drinking water from grocery stores. ${ }^{55}$ The second option was nearly as unattractive as the first, requiring storage of bathing and cleaning water in outdoor cisterns prone to insects, worms, snails, and parasites and necessitating chemical treatment before use. ${ }^{56}$ Community groups estimated that to purchase, haul, and treat their own water, residents paid up to, and sometimes more than, ten times the cost of public water service, as well as heightened insurance premiums for the lack of water for firefighting. ${ }^{57}$ One can only guess at the private costs borne in other unincorporated urban areas. Residents of California and Texas's numerous unincorporated urban areas located on flood plains, for instance, have incurred devastating property damage-including sewage tainted floodwaters washing through homes-stemming from the absence of drainage and flood-control infrastructure in their communities. ${ }^{58}$

Furthermore, unincorporated urban areas may face the perpetuation of economic disadvantage brought about by their isolation as county pockets within areas that have been economically cherry-picked for annexation to incorporated municipalities. In Broward County, Florida, for instance, city incorporations and annexations have consumed nearly every parcel of land that offers advantageous property tax revenues, whether commercial or residential. Today, the only urban residential areas remaining under unincorporated jurisdiction are clustered in a block of low-income neighborhoods that are nearly 100 percent African American. ${ }^{59}$ Divided from all

55. See Complaint T 3, Fair Housing Advocates Assoc. v. City of Zanesville, (OSI)H1071702 (29617) 080502 (S.D. Ohio Dec. 1, 2003).

56. See Ludlow, supra note 54, at 1A; see also Complaint पापा 33, 35, Zanesville, (OSI)H1071702 (29617) 080502; James Dao, Ohio Toun's Water at Last Runs Past a Color Line, N.Y. TIMES, Feb. 17, 2004, at A1.

57. See Complaint Tा 3, 34, 39, Zanesville, (OSI)H1071702 (29617) 080502; see also id. T 34 (describing other costs as well, including installation and maintenance of a cistern and pump, chemicals for treating water, bottled potable water, and repair and replacement of hot water tanks and appliances damaged by running contaminated water).

58. See WARD, supra note 27, at 30-32; Larson, supra note 14, at 191; Interview with Magdelena Mercado, Bret Harte resident, in Stanislaus County, California (Sept. 14, 2006) (on file with author).

59. In 1995, at the request of the Broward County Board of County Commissioners, the Broward County Legislative Delegation to the state legislature recommended that before 2010 , all unincorporated residential land in Broward County should be independently incorporated or annexed into one of the County's municipalities. See LEGISLATIVE COMM. ON INTERGOVERNMENTAL RELATIONS, OVERVIEW OF MUNICIPAL INCORPORATIONS IN FLORIDA 30 (Feb. 2001), available at http://www.floridalcir.gov/UserContent/docs/File/reports/muninc01.pdf. As a result of these efforts and the aggressive campaign of annexations that followed, the unincorporated population of the county fell from 127,374 in 2000 to an estimated 14,190 in 2006. See Broward County Urban Planning and Redevelopment Department Planning Services Division, Unincorporated Broward 
revenue-generating land, these communities have little hope for remaining economically viable on their own. The loss of the county's economy of scale in providing municipal services has meant that the cost of basic urban services in these areas now exceeds the cost of such services within city lines. ${ }^{60}$ To its credit-unlike many of the counties reviewed in the present study-Broward County has invested in the municipal services and physical condition of its unincorporated islands in order to improve their desirability for annexation; nevertheless, Fort Lauderdale and other adjacent municipalities have yet to annex them. ${ }^{61}$

When such conditions are aggregated, land ownership in unincorporated urban areas is burdened by handicaps. Such land is less valuable to hold over time, due to lethargic appreciation rates that reflect undesirable neighborhood conditions. Land in unincorporated urban areas can also be more costly to maintain and improve, with residents incurring costs such as property replacement after an uncontrolled flood and mitigation of contamination. Residents face the added costs of substituting for public services, such as by running a homemade streetlight on a home generator, buying and hauling clean water, and replacing a home septic system. And finally-of greatest risk to the economic stability of area households-homes in unincorporated urban areas are more likely to be lost through condemnation and redevelopment, as cities and counties work to increase the fiscal impact of area land by displacing residential uses. When overlaid with the long histories of segregation that led to these communities' establishment, these neighborhoods illustrate a material inheritance from racial discrimination and its capacity for race-neutral perpetuation through the high costs of poverty.

Conmty, 2006, BROWARD-BY-THE-NUMBERS, June 2006, at app. tbl. 2, available at http://www.broward.org/ planningservices/bbtn47.pdf. The few remaining residential unincorporated areas in the center of the county are between 94.1 and 98.2 percent African American. See Census 2000 Fact Sheets for Boulevard Gardens CDP, Roosevelt Gardens CDP, Franklin Park CDP, and Washington Park CDP, Florida, http://factfinder.census.gov (type city name under "city/town" and select "Florida" under "state"; then click "Go"); see also Map of Unincorporated Broward County, http://gis.broward.org/ maps/webPDFs/Unincorp/unincorp.pdf (last visited May 14, 2008).

60. Cf. BROWARD COUNTY BOARD OF COUNTY COMMISSIONERS, URBAN PLANNING AND REDEVELOPMENT DEPARTMENT PLANNING SERVICES DIVISION, COMPARISON OF MUNICIPAL FEES AND TAXES FOR THE MUNICIPALITIES AND THE UNINCORPORATED AREA OF BROWARD COUNTY, FISCAL YEAR 2008, at 5 (2008), available at http://www.broward.org/planningservices/upi00174.pdf (indicating that households in unincorporated areas pay property taxes, municipal service fees, and other municipal taxes that are higher than the average of Broward County's 81 municipalities); Jim Gaines, Annexation Vexation: The Plan to Bring Broward County's Poor Areas Into the Fold is Full of Holes, New Times Broward-Palm BeACH (FlORIDA), Aug. 23, 2001, available at http:// www.browardpalmbeach.com/2001-08-23/news/annexation-vexation.

61. See Gaines, supra note 60 . 


\section{Traversing Academic Categories}

Traditionally, black and Latino low-income suburbs have been seen through racially and regionally compartmentalized lenses. Among urban geographers, policymakers, and legal advocates, the study of colonias has been the dominant paradigm for understanding low-income Latino suburbanization. When studied at all, low-income black suburbanization is typically framed in terms of black rural poverty and municipal underbounding, both of which are characterized as southern patterns organized along a black-white racial axis. The nationwide, cross-racial concept of unincorporated urban areas distills the commonality among these three patterns, and they, in turn, help further define its contours.

\section{Municipal Underbounding}

"Municipal underbounding," a term coined by urban geographers, has been used to describe annexation policies and practices in which municipalities grow around low-income minority communities, leaving them outside the reach of city voting rights and municipal services. The term remains in use by some advocates today, including the University of North Carolina's Center for Civil Rights, the Southern Coalition for Social Justice, and the Cedar Grove Institute for Sustainable Communities, though the problem continues to receive sparse academic attention. With two notable, contemporary exceptions, ${ }^{62}$ academic research on the issue largely dates back to the 1970s and 1980s, when awareness of racially discriminatory annexation and incorporation policies reached its peak, both fueling and reflecting interpretative changes to the Voting Rights Act of $1965 .^{63}$ Empirical research into the problem has focused exclusively on white discrimination against African Americans in the South. ${ }^{64}$

62. See Lichter et al., supra note 18, at 51; Allan M. Parnell et al., The Persistence of Political Segregation: Racial Underbounding in North Carolina (Oct. 24, 2004), http://www.mcmoss.org/ CedarGrove/Docs/regional_underbounding.pdf.

63. 42 U.S.C. $\S \S 1973$ to 1973 bb-1 (2000). This period of attention is marked by, at the early end, the U.S. Supreme Court's decision in 1971 that Section 5 of the Voting Rights Act of 1965 reached racially discriminatory annexation and, at the later end, the Court's decision in 1987 that municipalities could not employ a racially discriminatory double standard in annexing white versus black neighborhoods. See City of Pleasant Grove v. United States, 479 U.S. 462, 466-72 (1987); Perkins v. Matthews, 400 U.S. 379 (1971). Major investigations of municipal underbounding include Symposium, The White Curtain: Racially Disadvantaging Local Government Boundary Practices, 54 U. DET. J. URB. L. 679 (1977), and Aiken, supra note 24.

64. See, e.g., Aiken, supra note 24; Lichter et al., supra note 18. 
Municipal underbounding is a critical component of the story of unincorporated urban areas, capturing the causal dynamic of municipal decisionmaking regarding annexations. Yet, like local government and urban policy literature in general, municipal underbounding focuses on cities as the relevant actors, largely overlooking causal factors related to the actions and incentives of settlers/residents, counties, and state governments. ${ }^{65}$ Such additional dynamics are discussed throughout this Article, but it is worthwhile to articulate here the two forces most necessary for a complete understanding of unincorporated urban areas. The first is the dynamic of low-income suburbanization itself-the pattern behind initial settlement and ongoing occupancy of unincorporated urban areas. I explain this pattern using the concept of an economic gravity model of urban change, discussed in Part II.B, in which segregation, affordability gaps, land-use barriers, and the aspiration for homeownership interact with the gravitational pull of the urban economy to spur low-income settlement at the urban fringe. Combining an economic gravity model of urban change with municipal underbounding reveals a broad dynamic of municipal exclusion in which low-income households are effectively barred from settlement in desirable subdivisions and residential neighborhoods in incorporated cities and suburbs (exclusionary land-use decisions); and, after settlement in alternative, unincorporated enclaves, these communities are locked in their unincorporated status and excluded from city growth that would have otherwise absorbed them (exclusionary boundary determinations).

Municipal underbounding and this broader formulation of municipal exclusion both fail to capture counties' roles in creating and perpetuating the condition and status of unincorporated urban areas. Counties, not municipalities, are legally responsible for the initial land-use approvals and service conditions of unincorporated urban areas. By virtue of their service standards for the establishment of new subdivisions, their purchase and allocation of the services needed in their jurisdictions, and the extent of their efforts to seek state and federal infrastructure grants to improve local conditions, counties are responsible not only for the establishment of everyday conditions of unincorporated communities, but also for their eligibility and desirability for annexation. In addition, it is counties as well as cities and state agency partners that enact infrastructure and land-use planning decisions that adversely affect unincorporated urban areas.

65. See Lichter et al., supra note 18 (anchoring a major study of municipal underbounding in the annexation behavior of cities). 
The nature and limitations of county rule of unincorporated urban areas is explored extensively in Part III.

Municipal underbounding is thus a necessary but insufficient lens through which to view the pattern of unincorporated urban areas. Annexation decisions are but one cause of unincorporated urban areas, and annexation should not be presumed to be the answer to these communities' needs in every case.

\section{Related Patterns: Colonias and Black Rural Poverty}

The unincorporated urban areas classification is also informed by its partial overlap with the land-use patterns known as colonias and black rural poverty. Colonias development refers to a pattern of low-income, primarily Latino, subdivisions named after the Spanish word for neighborhood. ${ }^{66}$ The term colonias encompasses communities built in both rural and peri-urban ${ }^{67}$ areas. Land subdivided for settlement as colonias must be inexpensive, while also profitable for subdivision and within range of agricultural, industrial, or other concentrations of employment. ${ }^{68}$ This combination has shaped the location and condition of colonias in at least two ways: Most colonias are found in unincorporated areas within states that have traditionally granted their counties minimal, if any, land-use or building-code enforcement powers; and most colonias lie on patches of desert, flood plains, steep slopes, and/or former industrial sites. ${ }^{69}$ Colonias lack most, if not all, collective infrastructure, ${ }^{70}$ and this fact has brought them to public attention primarily for the health risks caused by improvised, failing sewage disposal systems that

66. Under the operative federal definition, colonias include only those communities that (1) are in the states of Arizona, California, New Mexico, or Texas; (2) lie within 1.50 miles of the United States-Mexico border, excepting metropolitan areas with populations exceeding 1,000,000; (3) satisfy objective criteria, including a lack of potable water, an adequate sewage systems, and decent, sanitary housing; and (4) existed before November 28, 1990. 42 U.S.C. $\$ 1479(f)(8)(2000)$. I use the term "colonias" without limitation to its location along the United States-Mexico border-the broader sense of the term now common in academic literature.

67. Peri-urban areas are generally defined as communities that are outside of, but adjacent to, the boundaries of a city, but that share many of the characteristics of urban areas.

68. WARD, supra note 27.

69. Id.; Larson, supra note 14.

70. See Larson, supra note 14, at 194. Studies of colonias have documented, however, that many residents purchased their lots based on false information from subdividers that water and sewer lines would be forthcoming. See CHAD RICHARDSON, BATOS, BOLILLOS, POCHOS, AND PELADOS: Class and Culture on the SOUTH TEXas Border 43-44 (1999). 
have contaminated residents' water supplies." The absence of flood-control infrastructure has also exacted a severe toll in many colonias, permitting unabated floodwaters to destroy homes, amplify human exposure to ground contamination, and create accumulations of hazardous standing water. ${ }^{12}$

Despite some similarities with colonias, low-income, unincorporated African American enclaves have been seen through a different lens. Such communities are typically understood as incidents of black rural poverty, a pattern of socioeconomic decline in segregated rural and peri-urban enclaves of the South. Black rural poverty now far exceeds the rural poverty rates of any other ethnic group; indeed, in 47 percent of nonmetropolitan counties with poverty rates of 20 percent or more in 2000 , the majority of the poor were black, or it was only the high incidence of poverty among black households that brought the county's overall poverty rate above 20 percent. $^{73}$ This pattern is most prominent in the "cotton counties" that run through North Carolina, South Carolina, Georgia, Alabama, Mississippi, Louisiana, and East Texas, where slavery gave way to the indentured status of the sharecropping system and left behind some of the country's most severe inequities in education, poverty, and unemployment. ${ }^{74}$ Themes reminiscent of distressed cities-racial segregation, social isolation, a vanishing job base-now plague towns like Jonestown, Mississippi, which is dying in the Delta cotton fields after school integration in the 1960 s spurred the departure of the city's white economic base, leaving behind a population of no more

71. Public health risks in colonias have included vulnerability to cholera, outbreaks of viral infections, and myriad skin and intestinal disorders. See Larson, supra note 14, at 189-90; WARD, supra note 27 , at 7,9 .

72. See Larson, supra note 14 , at 191.

73. See U.S. Dep't of Agric. Econ. Research Serv., Rural Income, Poverty, and Welfare: HighPoverty Counties, http:/www.ers.usda.gov/Briefing/IncomePovertyWelfare/HighPoverty (last visited July 10, 2007).

74. See William W. Falk et al., Life in the Forgotten South: The Black Belt, in FORGOTTEN PlaCES: UNEVEN DEVELOPMENT IN RURAL AMERICA 53-56 (Thomas A. Lyson \& William W. Falk eds., 1993). The causes of black rural poverty are also linked to the failure to provide economic relief during the New Deal-including access to social security benefits, government grants, assistance to the elderly poor, and unemployment insurance--to African American sharecroppers, who were known to be among the hardest hit by the Great Depression; the dramatic fall in the number of black farm operators during the postwar period; the absence of highly skilled jobs in the economy of the Black Belt region in general; and the struggle throughout the past century of rural black families to hold onto their land. See generally IRA KATZNELSON, WHEN AFFIRMATIVE ACTION WAS WHITE: AN UNTOLD HISTORY OF RACIAL INEQUALITY IN TWENTIETH-CENTURY AMERICA (2005); John B. Cromartie \& Calvin L. Beale, Increasing Black-White Separation in the Plantation South, 1970-90, in RACIAL/ETHNIC MINORITIES IN RuRAL AREAS: PROGRESS AND STAGNATION, 57 (Linda L. Swanson ed., 1996), available at http://www.ers.usda.gov/publications/aer731/ aer731e.pdf; Falk et al., supra, at 63-73. 
than 1,500 people that is 95 percent black and overwhelmingly jobless. ${ }^{75}$ Among the pattern's most important spatial dimensions is the concentration of African Americans in de facto segregated rural hamlets and peri-urban subdivisions that, in many cases, are near former plantations where residents' ancestors lived under slavery. ${ }^{76}$ Some of these unincorporated fringe developments trace their roots to low-interest housing loans or federally funded public housing that was refused by the municipalities themselves, which have tended to avoid the annexation of these areas as they grew. ${ }^{77}$ As a result, segregation between fringe and municipality has increased, just as black-white segregation in the South in general has risen. ${ }^{78}$

The racial identities attached to the names of these two patterns, one signaled with language and the other with color, have isolated the patterns from one another, drawing scrutiny away from their underlying local government and economic structures and towards the people who occupy these spaces. By their very name, colonias are a racialized category-a label originally rooted in community pride and culture ${ }^{79}$ that, in certain policy and media contexts, has become a stigmatized expression denoting poverty, dilapidation, and filth. ${ }^{60}$ The use of the term in policy, government, and grantmaking contexts is suggestive of the pattern's branding as an importation from the Third World, a housing pattern that has leaked across

75. See Peter Applebome, Deep South and Doum Home, But It's a Ghetto All the Same, N.Y. TIMES, Aug. 21, 1993, at Al.

76. See Charles S. Aiken, New Settlement Patterns of Rural Blacks in the American South, 75 GEOGRAPHICAL REV. 383 (1985); see also Charles S. Aiken, A New Type of Black Ghetto in the Plantation South, 80 ANNALS ASs'N AM. GEOGRAPHERS 223 (1990). This pattern of white flight from rural municipalities in the South reached its peak between 1980-1990, with more than onethird of towns, cities, and rural villages experiencing growth in black populations and a decline in white populations. This flight drained towns of economic resources that had been built on slavery and sharecropping. See Cromartie \& Beale, supra note 74, at 61,63 .

77. See Aiken, A New Type of Black Ghetto in the Plantation South, supra note 76.

78. See id.; Cromartie \& Beale, supra note 74, at 62-64.

79. In the context of self-identification, the name "colonias" can be viewed as an act of cultural ownership, a label to capture the role of colonias as an ethnic neighborhood refuge. See, e.g., Colonias Housing and Community Development Assistance: Hearing on H.R. 4606 Before the Subcomm. on Hous. and Cmty. Dev. of the H. Comm. on Banking, Fin. and Urban Affairs, 100th Cong. 6 (1988) (statement of Henry B. Gonzalez, Chairman) (describing the origins of the word in identifying "our area, our folks" as newcomers clustered together to adjust to foreign or hostile environments).

80. See RiCHARDSON, supra note 70 , at 43 (citing news reports); see also Mukhija \& Monkkonen, supra note 29, at 476 (finding the term colonias to serve as a prejudiced signal that the problem was imported by Latino immigrants). This dichotomy between cultural affirmation and sanctuary, on the one hand, and an externally imposed state of segregation and stigmatization, on the other, imposes a similar tension on the term barrio. DAVID R. DIAZ, BARRIO URBANISM: ChICANOS, PlanNing, AND AMERICAN CitIES 3 (2005). 
America's southern border from Mexico. ${ }^{81}$ Similarly, a narrow focus on black rural poverty isolates the pattern as an idiosyncrasy of one racial group. While there is an important place for a focus on the extent and distinctive historical origins of poverty in rural African American areas, the study of other urban development patterns illuminates the extent to which the problem is not limited to one place, population, or race. In policy and media contexts, characterization of colonias and black rural poverty as racialized phenomena distracts from the decidedly American combination of low wages, inadequate education, scarce affordable housing, racially discriminatory allocation of services and regulation, and land-market exploitation that catalyzed such communities' development. ${ }^{82}$

The social construction of the colonias and black rural poverty frameworks has also artificially limited these patterns to specific regions of the country, blinding policy and grantmaking endeavors to the presence of similar communities elsewhere. Federal funding for infrastructure in colonias, for instance, is limited to border counties within border states, ${ }^{83}$ despite the fact that among advocates, the term colonias has moved northward, increasingly encompassing low-income unincorporated Latino communities with severe infrastructure needs anywhere in the country. ${ }^{84}$ Similarly, the nomenclature "black rural poverty" and its strong historical affiliation with the South have drawn attention away from scattered communities that are too far north, too racially heterogeneous, or too urban to fit the typical profile. ${ }^{85}$

81. Indeed, the U.S. Congress has called the problem "A Third World Within Our Borders"-a title suggestive not only of the impoverished conditions lying within the U.S., but of the problem's foreign origin. See Colonias: A Third World Within Our Borders: Hearing Before the H. Select Comm. on Hunger, 101st Cong. (1990). Yet, not surprisingly, the federal definition of colonias is not limited by the race of the occupants, and some of California's officially designated colonias are demographically heterogeneous. See Mukhija \& Monkkonen, supra note 29, at 479-83. The Spanish name for the pattern, however, overshadows this diversity.

82. See WARD, supra note 27, at 89; Richard Delgado, Rodrigo's Twelfth Chronicle: The Problem of the Shanty, 85 GEO. L.J. 667 (1997).

83. See 42 U.S.C. § $1479(f)(8)(2000)$.

84. See Mukhija \& Monkkonen, supra note 29; Nancy L. Simmons, Memories and Miracles-Housing the Rural Poor Along the United States-Mexico Border: A Comparative Discussion of Colonia Formation and Remediation in El Paso County, Texas, and Dona Ana County, New Mexico, 27 N.M. L. REV. 33, 37 (1997); see also Larson, supra note 26, at 145 (describing great variation among colonias despite important underlying commonalities).

85. For instance, Skeels and McElrath Park, African American unincorporated urban areas just outside the small city of Ravenna, Ohio, were identified as the poorest rural neighborhoods in the United States during the 1990s. These communities, settled by black workers during the boom years of World War II, continue to struggle against disinvestment, and they remain outside the borders of Ravenna, which is more than 90 percent white. See Grant Segall, Blacks Maintain Life Outside City Limits, CleVEland PLAIN DEALER, Feb. 21, 1999, at 1B. 
Many unincorporated urban areas would fall into the academic and policy categories of colonias and black rural poverty as described above. However, the definition of unincorporated urban areas developed in this Article is underinclusive of the patterns of black rural poverty and colonias insofar as colonias and black rural poverty encompass unincorporated areas that are not near an incorporated municipality, including rural settlements surrounded by agricultural land. The unincorporated urban areas definition is also overinclusive, reaching communities that might not fall within the typical understandings of colonias or black rural poverty because of heterogeneous racial demographics, high levels of urbanization, geographic location, and development origins. The sorting function provided by the definition and nomenclature of "unincorporated urban areas" emphasizes dependence on county government, proximity to city lines, neighborhood density, and poverty-four conditions that affect opportunities for and constraints on extending services, resisting adverse land uses, and improving political participation.

Linking colonias and black rural poverty through the broader concept of unincorporated urban areas reveals widespread common ground among all three patterns from the vantage point of local government and land-use law. Such communities tend to originate as highly unregulated subdivisions on unincorporated land, and they lack adequate public investment in the physical state of the neighborhood. They have experienced segregation and racial discrimination, tenacious poverty, a scarcity of housing alternatives, and in many cases, vulnerable or damaged land. The predominance of self-built housing, with improvised materials and construction methods, has resulted in poor and uneven building standards. ${ }^{86}$ As a consequence of these characteristics, such communities' unusually high rates of homeownership do not create the same prospects for financial stability and upward mobility as homeownership in other contexts. ${ }^{87}$

Colonias and black rural poverty are not interchangeable-community advocates have good reasons to remain aware of the patterns' distinct histories and cultural attributes. But key dimensions of their condition, including their dependence on county government, warrant unified attention. By placing colonias and black rural poverty within this larger

86. See Larson, supra note 14, at 192; ANDREW WIESE, PLACES OF THEIR OWN: AFRICAN AMERICAN SUBURBANIZATION IN THE TWENTIETH CENTURY (2004).

87. Indeed, it is estimated that 85 percent of colonias residents own their own homes. Larson, supra note 26 , at 152 . Instability in home prices in colonias is compounded by the legal uncertainty associated with the financing and titling mechanisms commonly used in the colonias market. See id. at 147. 
understanding, local government law and urban policy may begin to unravel underlying dynamics of causation and perpetuation. Looking through the wider lens of unincorporated urban areas also reveals the interplay of these patterns with municipal underbounding, providing a common rubric for nationwide, cross-racial academic and policy attention. Rather than representing southern, rural, Latino, African American, or border phenomena, we see that municipal underbounding, colonias, and black rural poverty represent a single civil rights issue that is rooted in unmistakably American legal origins.

\section{Beyond White Flight: Looking Towards the Low-Income Periphery}

Urban planners, geographers, and local government scholars have largely overlooked the pattern of unincorporated urban areas, because it fails to conform to the twentieth century's dominant paradigm in city growth, the white flight model of urban change. Under this familiar pattern-described in landmark works such as Cities of Tomorrow by Peter Hall ${ }^{88}$ and American Apartheid by Douglas Massey and Nancy Denton ${ }^{89}$ - wealthy households and commercial interests moved to outer suburbs, using independent municipal incorporation as a tool of antidistributivist isolation, tax advantage, and political control. ${ }^{90}$ The loss of high-income households (and thus high-ticket real estate and property taxes), jobs, and sales tax revenue-in combination with racial discrimination in suburban real estate and zoning practices ${ }^{91}$ - left behind a zone of predominantly black and Latino poverty in city centers. The resulting landscape of primarily white suburbs surrounding a high-poverty,

88. PETER HALl, CTTIES OF TOMORROW: AN INTELLECTUAL HISTORY OF URBAN PLANNING AND DESIGN IN THE TWENTIETH CENTURY (3d ed. 2002).

89. DOUGlas S. MASSEY \& NANCY A. DENTON, AMERICAN APARTHEID: SEgREGation AND THE MAKING OF THE UNDERCLASS (1993).

90. Cornerstone works of legal scholarship considering the distributive, local governmental, and economic impacts of this metropolitan fragmentation include, inter alia: GERALD FRUG, CITY MAKING: BUILDING COMMUNITIES WITHOUT BUILDING WALLS (1999); Richard Briffault, The Local Govermment Boundary Problem in Metropolitan Areas, 48 STAN. L. REV. 1115 (1996); Sheryll D. Cashin, Localism, Self-Interest, and the Tyranny of the Favored Quarter: Addressing the Barriers to New Regionalism, 88 GEO. L.J. 1985 (2000); Richard Thompson Ford, The Boundaries of Race: Political Geography in Legal Analysis, 107 HARV. L. REV. 1841 (1994); Laurie Reynolds, Intergovernmental Cooperation, Metropolitan Equity, and the New Regionalism, 78 WASH. L. REV. 93 (2003); David Dante Troutt, Ghettos Made Easy: The Metamarket/Antimarket Dichotomy and the Legal Challenges of the Inner-City Economic Development, 35 HARV. C.R.-C.L. L. REV. 427 (2000).

91. Suburban governments fostered economic and racial homogeneity using the power of zoning, the impact of which impact was amplified by racial steering, discriminatory mortgage lending, racial segregation in the placement of public housing, and racial covenants. See SHERYLL CASHIN, THE FAILURES OF INTEGRATION: HOW RACE AND ClASS ARE UNDERMINING THE AMERICAN DREAM (2004). 
racialized urban core is most prevalent in the large and historic metropolitan areas of the Midwest and the Northeast,$^{92}$ where the introduction of the automobile and automated mass transit stimulated radial layers of increasingly disparate development around an urban core.

Several decades of local government and urban policy scholarship have scrutinized the causes and consequences of inner-city poverty, including housing conditions and mobility at the lower rungs of the tenure ladder, polarization in wages and employment access, intensification of racial and economic segregation, and housing displacement stemming from urban redevelopment. Without taking anything away from this powerful work-which establishes the history by which twentieth-century urban policy will be judged - and the need for continued academic investment in these topics, the dominance of this framework has drawn attention away from economic and racial dynamics of newer cities and smaller cities across the country, where many low-income households live beyond city borders in low-income suburbs, drawn by the city's economy but excluded from the privileges of municipal political participation and the advantages of historically rooted public investment. ${ }^{93}$ Scholarship has thus understudied regional differences, particularly the expanding presence of suburban poverty in the South and the West. $^{94}$ In these regions, longstanding patterns of minority suburbanization have led to deeply rooted community histories and more even distributions of African Americans and Latinos between cities and suburbs. ${ }^{95}$

A public discourse focused on the dichotomy of white suburban idyll in contrast to black and Latino inner-city destitution has generated a perception of exaggerated universality in which the black and Latino poor are thought to live primarily in dilapidated inner cities. ${ }^{96}$ This perception of the inner city's

92. See Alan Berube \& William H. Frey, A Decade of Mixed Blessings: Urban and Suburban Poverty in Census 2000, in 2 ReDEFINING URBAN AND SUBURBAN AMERICA: EVIDENCE FROM CENSUS 2000, at 111, 114-16 (Alan Berube, Bruce Katz \& Robert E. Lang eds., 2005).

93. In contrast to low-income suburbanization, middle-class minority suburbanization has received long overdue attention in works such as Sheryll D. Cashin, Middle-Class Black Suburbs and the State of Integration: A Post-Integrationist Vision for Metropolitan America, 86 CORNELL L. REV. 729 (2001). In addition, scholars have tracked the outcomes of individual low-income families of color, particularly in Chicago, that have relocated to white, middle-class suburbs under court-ordered programs to distribute public housing across the metropolitan region. See, e.g., James Rosenbaum, Stefanie Deluca, \& Tammy Tuck, New Capabilities in New Places: Low-Income Black Families in Suburbia, in THE GEOGRAPHY OF OPPORTUNITY: RACE AND HOUSING CHOICE IN METROPOLITAN AMERICA 150 (Xavier de Souza Briggs ed., 2005); LEONARD RUBINOWITZ \& JAMES E. ROSENBAUM,

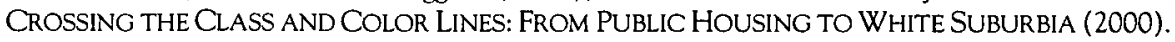

94. See Berube \& Frey, supra note 92, at 115-16.

95. See id. at $\mathbf{1 1 5 .}$

96. See John O. Calmore, A Call to Context: The Professional Challenges of Cause Lauyering at the Intersection of Race, Space, and Poverty, 67 FORDHAM L. REV. 1927, 1946 (1999). 
degraded social fabric has arguably polarized and aggravated race relations, while rendering invisible innumerable low-income minority communities outside core cities. A popular culture that continues to define suburbs as enclaves of cul-de-sacs, soccer moms, backyard super grills, and public school booster clubs with assumed white majorities excludes millions of low-income households that have sought family-friendly neighborhoods and upward mobility through suburbanization. ${ }^{97}$

The emphasis on white flight also means that contemporary urban policy and academic literature fail to account for urban neighborhoods without sewers and sidewalks the way that they account for the hopes and hindrances of inner-city neighborhoods. Poverty is less visible when it is outside the city, beyond the watchful eyes of central news outlets and suburban residents on their commutes to downtown jobs and services. Indeed, many of the land-use stories recounted here-neighborhoods divided by freeways or pinned between sewage plants and industrial facilities_-perpetuate ignorance of poverty at the fringe by spatially isolating unincorporated urban communities.

When we turn our attention to the city fringe, we also notice that unincorporated urban areas are closely related to two other urban patterns in which low-income, urbanized communities reside beyond the central city. First is the phenomenon of struggling, incorporated first-ring suburbs and other small towns. Poverty is shifting towards the suburbs in general, and independently incorporated first-ring suburbs (in large and small metropolitan areas alike) are becoming a particular locus of financial distress. The year 2005 marked the first time that American history has recorded more poverty in the suburbs than in the cities. ${ }^{98}$ Older cities in the South and Midwest (like Cleveland, Dallas, and Detroit) continue their struggle to adapt to the contraction of manufacturing, and their working-class populations, both urban and suburban, are slipping below the poverty line. 99 Many older central cities are

97. Historians of low-income and minority suburbanization, like Andrew Wiese and Becky Nicolaides, are now providing a long-absent foundation for alternative racial and economic geographies of urban space. See BECKY M. NiCOLAIDES, My BLUE HEAVEN: LiFE AND POLITICS IN THE WORKING-ClaSS SubURBS OF LOS ANGELES, 1920-1965 (Kathleen N. Conzen, Timothy Gilfoyle \& James R. Grossman eds., 2002); THE SUBURB READER, chs. 4, 7, 11, 14, 15 (Becky M. Nicolaides \& Andrew Wiese eds., 2006); WIESE, supra note 86. Urban geographers have similarly provided a crucial research foundation for understanding patterns of racial and economic change in American suburbs. See, e.g., MYRON ORFIELD, AMERICAN METROPOLITICS: NEW SUBURBAN REALITY (2002); Berube \& Frey, supra note 92.

98. Alan Berube \& ElizABeth KNEebOne, THE Brookings Inst. Metro. POlicy Program, Two STEPS BaCK: CiTY AND SubuRBAN POVERTY TRENDS 1999-2005 (2006); Peg Tyre \& Matthew Philips, Poor Among Plenty: For First Time, Poverty Shifts to the U.S. Suburbs, NEWSWEEK, Feb. 4, 2007.

99. BeRUBE \& KNEEBONE, supra note 98 ; Tyre \& Philips, supra note 98. 
fringed by historic black suburbs that independently incorporated during better economic times but today are fighting desperately to restore their tax bases and remain independently viable. ${ }^{100}$ The rural South similarly has a strong history of small (perhaps unsustainably so) residential communities of African Americans that proudly incorporated during the early decades of the century but today face severe challenges from withered tax bases. ${ }^{101}$ Development of an alternative understanding of urban change is equally relevant to these communities, which may soon represent another type of urban actor knocking at other cities' doors for inclusionary voting arrangements, regional revenue sharing, or consolidation. Changes to counties' institutional capacity to serve urbanized populations could similarly shift the possibilities for such communities, making the option of municipal dissolution more desirable.

A cities inside out framework also encompasses isolated but relatively dense high-poverty residential clusters that lie beyond the extraterritorial zoning jurisdiction of a municipality or other measure of a city's near term expansion territory. Research from the 2000 census revealed that more than 442 nonmetropolitan counties (out of a total of 2,308) had poverty rates of 20 percent or more. ${ }^{102}$ In a stunning 64 percent of these counties, the majority of the poor are African American or Hispanic, or it was only the high incidence of poverty among African American or Hispanic households that brought the county's overall poverty rate above 20 percent. ${ }^{103}$ Such communities range from topographically isolated rural hamlets to sprawling rural trailer parks with no collective services. These communities often exhibit both dramatic needs for municipal services and the overconcentration of undesirable land uses, but they are not candidates for annexation to an incorporated municipality or for the extraterritorial extension of

100. Such communities include Robbins, a historic black suburb settled on unincorporated land outside Chicago, as well as Venice and Brooklyn, suburbs of St. Louis. For a history of these three communities, see WIESE, supra note 86 . Robbins, for instance, had a per capita annual income of $\$ 9,837$ in 1999. See Robbins Village, Illinois, Census 2000 Fact Sheet, http://factfinder.census.gov (type "Robbins" under "city/town" and select "Illinois" under "state"; then click "Go") (last visited Mar. 30, 2008).

101. Taylortown, North Carolina, for instance, is a small residential hamlet that was founded in the early 1900s by the grandson of one of the first African slaves in America. The town's incorporation in 1987 enabled residents to obtain the municipal services denied to the other unincorporated Moore County residents discussed in this Article, but its aging population, loss of young people, and dwindling tax base present major viability challenges. See U.N.C. Ctr. for Civil Rights, Invisible Fences: Municipal Underbounding in Southern Moore County (2006), http://www.law.unc.edu/ documents/civilrights/briefs/invisiblefencesreport.pdf (citing research by Spencer M. Cowan, Ph.D., J.D., of the UNC Center for Urban and Regional Studies and UNC Center for Community Capitalism).

102. See U.S. Dep't of Agric. Econ. Research Serv., supra note 73.

103. Id. 
municipal services. ${ }^{104}$ Their location beyond the eyes and borders of surrounding cities makes their abandonment a less visible (though no less resonant) call to the state and local conscience.

Distinctions within these related patterns arise from the nature of their needs and the range of possible solutions, such as their eligibility for annexation, the influence of an adjacent city's regulatory power or political influence, and the empowerment and proximity of existing local government. In recognition of these important differences, this Article focuses on only one category-- those living under county government but near city lines. This proximity to city borders may provide a normative and/or legal claim to municipal inclusion, and it offers the potential to extend services from the municipal grid. Yet important common origins exist, with many communities of all three types built as workforce housing borne of low wages, segregation, and the desire for landownership. All have been disadvantaged by falling levels of local agency funding, and many have faced the dumping of hazardous or otherwise undesirable land uses in their communities.

When we look past white flight to discover new patterns of urban change, we encounter understudied patterns such as low-income homeownership, gentrification and displacement in suburban or semi-rural settings, environmental injustice at the urban fringe and agricultural interior, the costs and dangers of homemade infrastructure, neglect and passivity by remote law enforcement, and slumlords operating vast stretches of rural housing. Recent events show the vulnerability in this blindness. Low-income mortgages have collapsed in highly concentrated spatial clusters within older suburbs. ${ }^{105}$ Catastrophic loss of life and property beset New Orleans' Ninth Ward during Hurricane Katrina, where the greatest poverty meant the greatest exposure to risk. ${ }^{106}$ And each day brings private stories: children killed for lack of a sidewalk in the urban streets of Stanislaus and water pulsing with dangerous contaminants from taps in Tulare. ${ }^{107}$

104. Spatially isolated, high-poverty unincorporated communities include, for instance, the desperately impoverished rural mobile home parks of the Coachella Valley in California's Riverside County, where thousands of the region's farm and construction workers pack into unheated trailers without clean water or proper sewage disposal. Compounding their household deprivations, local air is choked with fumes from nearby illegal toxic dumps and pyres of hazardous waste. See David Kelly, The Southland's Hidden Third World Slums, L.A. TIMES, Mar. 26, 2007, at A1.

105. See Erik Eckholm, Foreclosures Force Suburbs to Fight Blight, N.Y. TIMES, Mar. 23, 2007, at A1.

106. See, e.g., Susan E. Howell \& John B. Vinturella, Forgotten in New Orleans, N.Y. TIMES, Apr. 20, 2006, at A1.

107. See, e.g., Daryl Farnsworth, Tragedy Strikes Family Again, THE MODESTO BEE, Dec. 1, 2002 (reporting the death of two boys walking with their mother in an unincorporated urban area); Interview with Magdelena Mercado, supra note 58; Interview with Eunize Martinez, resident of Tooleville, California, in Tooleville, California (Apr. 11, 2008). 


\section{ORigins, Persistence, ANd Perpetuation}

Peeling away the assumption of radial metropolitan regions characterized by inner-city poverty and suburban wealth reveals a slumbering history of low-income minority suburbanization, as well as an array of understudied economic and social forces animating that history.

\section{A. The History of Unincorporated Urban Areas}

When we look to the periphery, we find vestiges of nineteenth-and twentieth-century urban history: post-emancipation African American settlements across the South, hillsides and hollows in the Midwest that housed African American industrial workers of the Great Migration, and arid residential patches of the Southwest that have absorbed more than fifty years of Latino labor migration. Dating back twenty-five years or more (in some cases, more than a century), unincorporated urban areas form lasting gaps in the path of city growth, both bearing witness to and actively entrenching the history of racial exclusion that led to the neighborhoods' establishment.

Self-built, low-income minority settlement at the unincorporated periphery has been widespread since the nineteenth century. Indeed, "the first Americans to flee to the suburbs for racial reasons were black, not white." ${ }^{108}$ Spurred by the "living out" movement in the urban South, families of slaves and free blacks moved to the suburban fringe as a means to achieve privacy and independence from white masters while maintaining access to employment such as factory work and domestic labor. ${ }^{109}$ An unincorporated and unregulated hinterland provided space for development for "anyone with a few dollars for a down payment" for many decades before the era of the automobile, and the exclusion of blacks and Latinos from incorporated municipalities caused their relocation to this unregulated periphery. ${ }^{110}$ Black residence in blue-collar urban clusters and rim villages at the city fringe was a characteristic prewar development pattern of the South. ${ }^{11}$ Some of these prewar neighborhoods remain unincorporated urban areas today, including clusters in Moore, Orange, and Alamance Counties, North Carolina.

108. KENNETH T. JACKSON, CRABGRASS FRONTIER: THE SUBURBANIZATION OF THE UNITED STATES 18 (1985).

109. See id. at 18 ; WIESE, supra note 86 , at $17,19$.

110. See DIAZ, supra note 80 , at 31-32; see WIESE, supra note 86 , at 43,117 . Apart from the presence of a few very wealthy enclaves of elite estates, the suburbs of the early nineteenth century were actually economically weaker than cities. See JACKSON, supra note 108, at 18-19; WERNER TROESKEN, WATER, RACE, AND DISEASE 36-37 (2004).

111. WIESE, supra note 86 , at 5-6, 18 . 
The era of the Great Migration is best known for African American movement into central cities as whites began moving into the suburbs, ${ }^{112}$ but it is widely overlooked that this migration also triggered African American suburbanization in housing clusters near industrial facilities; enclaves for domestic workers in affluent rail and trolley line commuter suburbs; rustic, unplanned suburbs without services; and a few small bungalow suburbs for the prewar black middle class. ${ }^{113}$ Though such communities were less common in the North and the West, by 1940, one-fifth of African Americans lived in suburbs. ${ }^{114}$ Chagrin Falls Park, Ohio, for instance, one such community that remains an unincorporated urban area today, was settled in the 1920s by working-class African American Clevelanders seeking a return to their southern rural roots. ${ }^{115}$ Across the Southwest, a similar low-income urban form was emerging for Latino workers, with residential nodes developing near rail lines, manufacturing facilities, and agricultural districts on the urban periphery. ${ }^{116}$

Until World War II, nonwhites were more likely to their own homes than whites, particularly at the suburban fringe. ${ }^{117}$ Many of these communities were situated on inexpensive land that was vulnerable to nuisance or natural disaster and/or physically isolated from other city development by railroad tracks, topography, rivers, and other barriers. ${ }^{118}$ Neglect by white officials, often compounded by community need to keep housing costs low, resulted in a lack of rudimentary infrastructure, including paved streets, sewers, utilities, and water. ${ }^{119}$ These unplanned, unregulated communities retained a rural character —embodied by backyard husbandry and subsistence farming - that reflected the importance of self-sufficiency during times of employment insecurity. ${ }^{120}$

Concurrently, in the 1940s and 1950s, expansion in American agriculture and industry fueled the Bracero program, which authorized the entry of migrant workers from Mexico and other countries and led to the

112. TROESKEN, supra note 110 , at 36-37. Within the narrow period of 1920 to 1940 , the percentage of African Americans living in urban areas jumped from one-third to nearly one-half. See id. at 10 .

113. WIESE, supra note 86 , at $23-30$.

114. Id. at $5,15,20$.

115. See id. at 69.

116. See DIAZ, supra note 80 , at 32-35.

117. WIESE, supra note 86 , at 69,87 .

118. See DIAZ, supra note 80 , at 32; WIESE, supra note 86 , at 18 .

119. See WIESE, supra note 86 , at 17 ; see also DIAZ, supra note 80 , at $34-36,38$; JACKSON, supra note 108 , at $130-31$.

120. WIESE, supra note 86, at 19. 
development of housing for temporary workers on unincorporated land. ${ }^{121}$ The end of the Bracero program in 1964 did little to stop cross-border migration, but it did mark the end of its worker housing programs, leaving decades of recent immigrants and first-generation Mexican Americans unable to afford market-rate rental housing or mainstream home financing. ${ }^{122}$ To fill this gap, and in the absence of substitute federal housing programs, the colonias housing pattern thrived in the 1960s along the United StatesMexico border, particularly in Texas. ${ }^{123}$ Steady growth of the pattern continued in the 1970s and rapidly accelerated in the 1980s. ${ }^{124}$

The suburban floodgates of the postwar period, now a well-known urban narrative, had the effect of pushing growth out to the existing minority fringe developments, some of which were annexed to urban and suburban municipalities, others of which remained islands of unincorporated land. ${ }^{125}$ Once subsumed within the larger urban fabric, displacement pressures occurred, though we know little about the dynamics or extent of such transformations. ${ }^{126}$ While the midcentury proliferation of middle-class suburbs changed the economics and the laws governing development of unincorporated land near city borders, it did not stop the pattern of low-income peripheral development. Segregation effectuated by Federal Housing Administration financing, racially restrictive covenants, exclusionary zoning, and real estate steering and blockbusting continued to push many low-income blacks and Latinos into the unincorporated interstices of metropolitan areas, such as Long Island and Los Angeles, that had fragmented into numerous incorporated suburbs. ${ }^{127}$ In some cases, these groups first settled in ethnically

121. WARD, supra note 27 , at 89.

122. Id.

123. Id.

124. See Mukhija \& Monkkonen, supra note 29, at 477.

125. See DiAZ, supra note 80 , at 36 .

126. See generally DIAZ, supra note 80 , at 36 . Scholarship in urban studies and history displays a yawning gap in understanding this transition and the dynamics of land loss at the urban fringe. In particular, research remains to be done regarding the fate of early low-income fringe communities under pressure from the increased land values triggered by explosive suburbanization. One study of African American communities in Long Island between 1945 and 1960 found that unincorporated black neighborhoods largely escaped displacement by the urban renewal and slum clearance programs that displaced black neighborhoods in nearly every incorporated suburb of Long Island. See Andrew Wiese, Racial Cleansing in the Suburbs: Suburban Government, Urban Renewal, and Segregation on Long Island, New York, 1945-1960, in CONTESTED TERRAIN: POWER, POLITICS, AND PARTICIPATION IN SUBURBIA 61, 63-64 (Marc L. Silver \& Martin Melkonian eds., 1995).

127. See WIESE, supra note 86 , at $8,40-43,107,117$; Wiese, supra note 126 , at $61-65$; id. at 65 (describing that by 1950 , as many as one-third of the African Americans in Long Island lived in unincorporated areas). Research on the Old South indicates that in many small towns, African Americans displaced by urban renewal and slum clearance programs from neighborhoods within town lines were strategically rehoused at the unincorporated fringe, where they could be 
diverse unincorporated urban areas, but African Americans and Latinos ended up as the sole occupants as Jewish, Italian, Japanese, Russian, and other groups departed for more affluent, incorporated suburbs with stronger exclusionary zoning powers. ${ }^{128}$ East Los Angeles and other unincorporated minority suburbs considered incorporation as a means of emulating the advantageous contract city model pioneered in white suburbs, but many of these attempts failed due to insufficient tax bases, leaving hundreds of thousands of residents under county rule, where they remain today. ${ }^{129}$

The days of truly unregulated county land are over in most of the country, as counties have increasingly acquired zoning, building regulation, and enforcement authority. ${ }^{130}$ Yet even today, it remains the case that most county subdivision regulations fall short of requiring the range of services required for safe and sanitary habitation at suburban densities, and counties often lack sufficient personnel to enforce their codes vigorously. Even where compliance with counties' shallow minimum standards occurs at the inception of a subdivision, it may not prove adequate over time as physical conditions deteriorate and overall density in surrounding areas increases. ${ }^{131}$

excluded from town elections. See Charles S. Aiken, The CotTon Plantation SOUTH Since THE CIVIL W AR 320-27 (1998).

128. See Eric Avila, Popular Culture in the Age of White Flight: Fear and FANTASY IN SUBURBAN LOS ANGELES 51-52 (2004).

129. Residents of East Los Angeles, citing the need for improved services and political accountability, attempted independent incorporation in 1961, 1963 and 1974. See GARY J. MILLER, Cities By CONTRACT: THE POLITICS OF MUNICIPAL INCORPORATION 138-40 (1991); BuRR CONSUlting, REPORT tO THE EAST LOS ANGELES ResidentS ASSOCIATION, PUBliC REVIEW DRAFT: INITIAL FISCAL ANALYSIS OF PROPOSED INCORPORATION 6-7 (Oct. 25, 2007), http://www.cityhoodforeastla.org/files/PDFs/ELARA_IFA.pdf [hereinafter EAST L.A. RESIDENTS ASS'N REPORT].

130. The best illustration of this evolution is Texas. Until the 1990 s, the state retained a system of relatively powerless county government with little or no authority to regulate minimum public services and infrastructure in subdivisions. Though counties in Texas continue to lack the full scope of land-use regulatory authority common in other states, reforms in the 1990s granted counties some powers to regulate subdivision development and published model subdivision rules concerning minimal water, wastewater disposal, street paving, and flood control. See Larson, supra note 14, 197-200; WARD, supra note 27, at 98-114.

131. Indeed, many of the unincorporated urban areas discussed in this Article came to public light due to the health and environmental hazards caused by septic systems failing because residents could not afford replacement systems, or because area soil types had become saturated or otherwise incompatible with septic leeching. County decisions to enable development with a home sewage disposal system at its inception are unsustainable if at the expiration of a code-compliant home septic system (about twenty to thirty years), no private or governmental entities can pay the steep costs of replacement or upgrade to city sewers. In the normal course of suburban evolution for other communities, wealthier subdivisions built with septic systems were eventually annexed or incorporated into a municipality, and federal grants, local special assessments, and general municipal revenues funded the replacement of septic systems with city or special district sewer lines. See ADAM ROME, BULlDOZER IN THE COUNTRYSIDE: SUBURBAN SPRAWL AND THE RISE OF AMERICAN 
Counties that fail to regulate and to require the provision of services tend not to provide them either, approvals for large-scale development notwithstanding. Development pressures on unincorporated land will undoubtedly continue, compounded as service economies replenish the fiscal health and land values of many cities and exclusionary zoning practices persist. For reasons discussed in the next section, working-class families priced out of city property values continue to be drawn to neighborhoods at the unregulated edge.

\section{B. An Economic Gravity Pattern of Urban Development}

As is well understood in the context of international development, jobs attract workers, and workers need housing, whether or not the private market or the government provides and serves such housing. ${ }^{132}$ Well understood in the context of the American middle class, the aspiration for neighborhoods with "family values, youth values, and the blessings of quiet seclusion and clean air"133 is a powerful social force, propelling many households to seek lower-density residential settings. ${ }^{134}$ Where the market and the state fail to build affordable housing that satisfies people's preferences, self-help patterns emerge, with low-income workers settling on the least regulated, most affordable land in the metropolitan region. ${ }^{135}$ The urban fringe can satisfy these economic and cultural trajectories with its relative proximity to employment, rock-bottom land prices, and promise of space, sustenance, and homeownership.

I call this understudied interaction of employment magnetism, housing necessity, and suburban aspiration an "economic gravity pattern" of urban development. It directs our attention to the city periphery, where we find not only a widely-overlooked story of twentieth-century urbanization, but also some of the most important dynamics in contemporary local governance.

ENVIRONMENTALISM 87-118 (2001); see also id. at 111 (describing $\$ 30$ billion in federal subsidization of suburban sewer construction, "a goodly share" of which funded the replacement of septic tanks).

132. See generally MIKE DAVIS, PLANET OF SLUMS (2006) (giving a global portrait of informal settlements throughout the developing world); SASKIA SASSEN, THE GLOBAL CITY: NEW YORK, LONDON, AND TOKYO (2d ed. 2001); URBAN INFORMALITY: TRANSNATIONAL PERSPECTIVES FROM THE MIDDLE EAST, LATIN AMERICA, AND SOUTH ASIA (Ananya Roy \& Nezar Alsayyad eds., 2004).

133. Vill. of Belle Terre v. Boraas, 416 U.S. 1,9 (1974).

134. See generally THE SUBURB READER, supra note 97; ROBERT BRUEGMANN, SPRAWL: A COMPACT HISTORY (2005) (describing the history of urban decentralization and the evolving meaning of the word sprawl).

135. See Larson, supra note 26, at 153-55. See generally Larson, supra note 14, at 185, 197-99. 
Economic gravity describes the magnetic pull of a metropolitan economy, expressed in the tendency of households of all income levels to settle as close as possible to employment sources, commercial offerings, schools, government hubs, and urban amenities, but according to the constraints of exclusionary zoning and household needs and preferences in terms of land values, lot sizes, and proximity to open space. ${ }^{136}$

For some low-income households, the pull of economic gravity has meant tolerance for concentrated poverty in highly urbanized pockets in the center city; for others, it has meant settlement in makeshift suburban-style housing in the unincorporated zone at or near the city border. Even in counties where major low-wage employers are located at scattered agricultural and industrial sites away from central municipalities, the urban fringe can offer balance between access to employment and access to urban amenities. Though lacking in many essential services, the fringe is more likely to provide access to single-family homes and the opportunity for land ownership. ${ }^{137}$

Development in unincorporated areas at or near the city fringe is also less expensive for at least two reasons: lower land values due to the absence of existing urban services and increased distance from urban amenities and the absence or weakness of building regulations and enforcement mechanisms. This lack of regulatory oversight or segregation of land uses may permit subsistence agriculture, animal husbandry, and home businesses, which provide supplemental family income, economic stability, and sustenance for low-wage, often seasonal workers. ${ }^{138}$ Lax regulatory control can also mean, however, that developers are permitted to juxtapose low-income residential subdivisions with undesirable land uses or site such communities on disasterprone land. Such locations keep land prices low and make annexation by a neighboring municipality less likely.

136. In its broadest sense, an economic gravity model has been implicit in our understanding of metropolitan areas built on the economic engines of historic cities, though our language has focused instead on the concept of centrifugal flight or sprawl from the city. An explicit focus on gravitational dynamics represents a shift in perspective for two reasons. First, it highlights those economic dynamics that pull a region's employers and employees (and consumers and commercial activities) together, rather than focusing on those dynamics that splinter it apart. Second, unlike the concepts of flight and sprawl, it does not prejudice the question of whether suburban settlement represents a conscious choice made in the face of meaningful alternatives. Due to the widespread barriers to affordable housing in so many family-friendly, centrally located residential areas, settlement in outerlying areas may be less voluntary than inevitable.

137. Studies of colonias housing have found that home ownership serves as a "powerful symbol of self-reliance, personal dignity, and family advancement," and residence in colonias expresses aspirations for a suburban pastoral of rural open space and personal safety. See Larson, supra note 14, at 206.

138. See, e.g., Larson, supra note 14, at 208; WIESE, supra note 86, at 69. 
In these conditions, we encounter one of the most important tensions at the city's edge: spatial exile and government abdication, embodied by the lack of collective infrastructure or the concentration of undesirable land uses, can enable low-income families to achieve the dream of buying land and building a home. With this freedom and this risk, residents of the fringe have labored to create their own suburban refuges, forged strong bonds of family and community loyalty, and developed a pride of place that would chasten any outsider's empathetic indignation. Yet it would belie their history not to notice the numerous crossroads at which the absence of government has also weakened unincorporated urban areas' ability to resist false promises and exploitation in private land markets, the concentration of undesirable land uses, redevelopment in the economic interests of outsiders, and, in many cases, outright displacement and land loss. Several decades of federal housing policy subsidized suburbanization through transportation, water, and sewage treatment infrastructure financing that passed by unincorporated urban areas.

An economic gravity pattern of urban change not only reclaims the struggle and self-sufficiency of low-income families who have fought to secure the suburban dream of open space and homeownership, it shifts our vantage point in the local autonomy and regional equity debate. Unincorporated urban areas represent a low-income outsider community serving as an insider labor pool for a municipal or regional economic market and, as such, they lead us to ask whether it is just to exclude them from municipal services and governance. Unified economic networks, even in smaller cities, invite expansion of the notion of the community entitled to self-government and regional service equality. ${ }^{139}$ In the local autonomy debate, these areas illuminate the way that we have unwittingly privileged existing municipalities' claims of self-government over the inclusionary claims of outsiders, thus preferring some groups' claims to local autonomy over others' claims for any local entity at all. From a local autonomy perspective, for instance, one would question whether annexation of unincorporated urban areas would dilute the small-scale participatory democracy enjoyed by existing residents in a city, but in so doing, ignore the participatory effects of

139. Richard Schragger's conceptualization of the "communities" underlying the local autonomy debate-political bodies defined in relation to other plausible, alternative communities-is thus manifested in the pattern of unincorporated urban areas. See Richard C. Schragger, The Limits of Localism, 100 MICH. L. REV. 371, 373, 464 (2001). Due to integration with municipal life in terms of economic, social, educational, and transportation networks, residents of unincorporated urban areas are in the position to make a "horizontal" claim, id., that they belong to the relevant community affected by municipal politics and thus should be included within the zone of municipal political rights. 
that exclusion on the existing minority population in the city and its unincorporated urban areas, who enjoy no right to municipal participation at all.

The concept of economic gravity also helps us to better understand sprawl, with its well-documented effects of traffic congestion, destruction of open space, air pollution, and racial and economic homogeneity. ${ }^{140}$ Unincorporated urban areas teach us about the early processes of sprawl, such as the leapfrog development of affordable housing to the urban fringe and the largely unregulated sale of unincorporated land. They also reveal one of sprawl's understudied consequences: the construction of poor communities without the prior establishment of services necessary for health, safety, and property appreciation. The problem of unincorporated urban areas thus uncovers several tensions in environmental and infrastructure policy related to, on the one hand, the importance of development limits in cities' green belts or spheres of influence and, on the other hand, the environmental hazards of improvising or going without municipal services at the rural-urban periphery.

Perhaps most importantly, looking towards the periphery also brings our attention to the problem of land loss. ${ }^{141}$ Homeownership tenure in areas at risk for condemnation, legal exploitation, and redevelopment heightens households' vulnerability to devastating financial loss. High levels of physical deterioration and sanitation problems verging on legal uninhabitability, as well as myriad building code violations that could warrant condemnation orders augment this risk. Like the slum clearance programs of old, modern redevelopment programs pose the risk of displacement before improvement. Even where communities are not at risk for absolute displacement, real property devalued by a history of municipal exclusion or other form of racial discrimination is a form of property loss in the sense that it artificially depresses land values. The effect can tip a neighborhood towards further

140. See BRUEGMANN, supra note 134, for a history and examination of sprawl in urban and exurban (i.e., prosperous rural commuter areas just beyond suburbs) areas.

141. This vulnerability is best understood in the context of black rural poverty, which is both a cause and an effect of the dramatic pattern of continual black land loss across the South since 1910 . In a "remarkable and improbable" triumph over history, black farmers acquired sixteen to nineteen million acres of agricultural land, primarily in the South. Thomas W. Mitchell, Destabilizing the Normalization of Rural Black Land Loss: A Critical Role for Legal Empiricism, 2005 WIS. L. REV. 557, 563. By 2002, that number had fallen to about 2.2 million acres. Id. An eighteen-month investigation into the causes of black land loss indicated that patterns of heir property and partition sales (by which a single heir to an undefined portion of real property triggers the court-ordered sale of the entire property to the highest bidder, often a nonfamily member) were a common cause, but that fraud, intimidation, and violence also explained a high percentage of forced land sales. See Todd Lewan \& Dolores Barclay, Torn From the Land: Black Americans' Farmland Taken Through Cheating, Intimidation, Even Murder, ASSOCIATED PRESS, Dec. 2, 2001, available at http://www.commondreams.org/ headlines01/1202-03 htm. 
deterioration or complete displacement by condemnation, exploitative land speculation, and/or gentrification.

Finally, at a structural level, the economic gravity model of urban development challenges the contemporary assumption that outlying areas resist annexation due to tax effects. Rooted in the postwar flight to the suburbs, the narrative of resistance to annexation assumes its protagonist suburbs to be higher-income, and it emphasizes these suburbs' economic and political advantages as smaller units. Local government literature, which widely emphasizes, if not takes for granted, this aggressor-city model of annexation, commonly features contests for power and economic advantage between cities and incorporated suburbs, in which annexations are described as a means of consolidating center-city power at the expense of independent suburban municipalities' autonomy interests, tax rates, and the service quality. ${ }^{142}$ This story is not untrue, but it is incomplete. Annexation is not necessarily a panacea or a burden, but as Part III explains, the political limitations of county government summon our attention to the potential advantages - in terms of democratic accountability as well as administrative efficiency $\longrightarrow$ of bringing unincorporated urban areas under municipal authority.

Understanding annexation in this broader context-in which poor communities seek inclusion within stronger and larger tax bases-will be crucial for twenty-first century urban policy and local government law..$^{143}$ Unincorporated urban areas, just one example of this dynamic, are unlikely prospects for independent incorporation precisely because of their lower land and property values (and thus the lower property tax potential there) and the absence of a commercial property or sales tax base. Instead, as incorporated municipalities grow out to meet them or grow past them, annexation is the only alternative to unincorporated urban areas remaining as isolated urban pockets of county jurisdiction. The question then becomes whether the city wishes to take or to exclude their land.

\section{URBAN LIFE WITHOUT URBAN GOVERNMENT}

The challenges in unincorporated urban areas are not unique. Nodes of urban poverty located within municipalities struggle against the ills of political

142. The U.S. Supreme Court's most direct foray into questions of municipal annexation addresses this scenario of growth resistance by suburbs, holding that there is no constitutional right to resist absorption by a larger municipality. Hunter v. City of Pittsburgh, 207 U.S. 161 (1907).

143. See Anderson, supra note 3 (proposing legal reforms to annexation laws that respond to the unincorporated urban areas issue). 
neglect and material decline. Yet unincorporated urban areas' dependence on counties as their most proximate tier of general purpose local government distinguishes these communities from high-poverty neighborhoods within city lines. This Part investigates the difference this status might make, taking a first step towards understanding counties' unique political economies and their capacity and performance at serving urban populations. To undertake this inquiry, I provide a framework for evaluating local government-a way of analyzing whether people have the right kind of local government to suit local needs and preferences-and then apply this model to unincorporated urban areas. I use the analysis of institutional incentives and capacity, paired with case studies, to explore the differences between county and city governments' stewardship of urban areas.

I focus here on the governmental status of unincorporated urban areas, because local governments continue to wield tremendous power to advance or to thwart the consequences of residential segregation underlying unincorporated urban areas' development. Unincorporated urban areas manifest the legacy of segregation expressed not only in terms of racial separation, but in terms of hierarchies of land quality and location. The land beneath many of these communities remains today, as it was at the time of settlement, inherently defective or burdened due to one or more of three adversities: contamination or the risk of natural hazards; decades of reduced public investments in infrastructure, services, and brownfield abatement; and the overconcentration of undesirable land uses that reduce neighboring property values and threaten community health. ${ }^{144}$ Local governments are key actors in preserving or correcting these disadvantages. They act as gatekeepers of newcomers to local jurisdictions, including industrial uses; they hold regulatory powers that shape the material conditions of neighborhood life; they advocate to bring private and intergovernmental resources into their locales; and they serve as forums for participatory democracy. While other factors (most importantly, labor markets and wage structures) also weigh on the conditions in unincorporated urban areas, local governments independently affect the real property assets of communities defined by the legacy of residential segregation.

\section{A. A Model for Evaluating Local Government Adequacy}

The endeavor of evaluating local governments requires a normative perspective-a point of orientation for determining what makes a local

144. See supra Part II.B. 
government suitable and adequate. I have captured this normative perspective in three dimensions. Residents need a meaningful option to stay in their homes, or if they wish, to move; safe, sanitary material conditions that support quality of life, protect public and environmental health, and enable property appreciation; and the power to organize to improve local conditions. These values amount to a conceptualization of local government adequacy as: (1) choice and mobility in the housing market; (2) habitability in terms of collective services, as well as air, soil, and water quality; and (3) political access and representation. This conceptualization represents a synthesis of theoretical insights from fair housing law (seeking formal racial equality among homeseekers as well as nondiscriminatory allocation of public resources), voting rights law (enabling minority communities to draw political will towards their neighborhoods), public choice theory (emphasizing the interaction of housing mobility and local government political accountability), and political and institutional economic theory (exploring the institutional incentives of local governments and the pathways of reform available to persons seeking to change local government behavior).

Housing choice and mobility, the first of these factors, lies at the heart of economic analysis of local government behavior and fair housing law. Its first dimension is the ability to exit-residents' freedom to move in search of more desirable combinations of taxes, services, and environments. Exit is a linchpin of public choice theory in the local government context, which posits that mobility justifies a broad sphere for local autonomy; the threat that people will "vote with their feet" by moving in search of suitable locales serves as an inherent check on local government behavior. ${ }^{145}$ Exit values are also a premise of fair housing laws, which seek to permit racial minorities to exit segregated, high-poverty areas characterized by physical decline and political failure.

Housing alternatives (in other words, the option to enter alternate jurisdictions) are a necessary condition of exit. By leaving its existing home, a family must be able to acquire an equally or more satisfactory-yet affordable-housing product. For homeowners, both exit and entry require that residents' current homes hold their value (thereby avoiding a loss penalty at the time of sale) and appreciate at rates approximately commensurate with the regional housing market (thereby permitting owners

145. The launch of these thousand ships was, of course Charles M. Tiebout, A Pure Theory of Local Public Expenditures, 64 J. POL. ECON. 416 (1956). The influence of Tiebout's hypothesis is captured in William Fischel's edited volume THE TIEBOUT MODEL AT FIFTY: ESSAYS IN PUBLIC ECONOMICS IN HONOR OF WALLACE OATES (William A. Fischel ed., 2006). For a critique of Tiebout's theory see MILLER, supra note 129, at 61-62, 68 . 
to acquire a better housing product without falling on the tenure ladder from homeowner to renter). For renters, housing alternatives require the maintenance of affordable housing within a wide range of jurisdictions, permitting households to exert preferences beyond mere affordability itself, such as school quality, access to open space, safety, and proximity to employment. Entrance has thus become a central theme in local government law, with a rich exploration of zoning and boundary setting devices, including incorporation and annexation, that establish homogeneous jurisdictions that exclude nonconforming outsiders. ${ }^{146}$ Applying an integrationist perspective primarily in the context of white flight, this scholarship has identified the barriers erected by middle- and upper-class white suburbs seeking to exclude low-income, particularly low-income minority, residents.

A housing market that facilitates mobility and housing choice does not mean that local government spurs the departure of costly residents. Instead, a local government's stewardship of its residents' housing choices requires the option to stay in one's existing home and neighborhood. This option, in turn, enables residents to discipline their local government's decisions and to justify the breadth of local government autonomy. Such an inquiry preserves a concern about local government capacity to entrench or to ease the neighborhood hierarchies grafted by segregation, but it shifts our focus on that question. For people who have fought tenaciously to hold on to their land and might choose to continue holding it, are their current local governments supporting or undermining fair housing and voting rights? With respect to existing residents of a jurisdiction, not putative entrants to it, are local governments perpetuating the community disadvantages organized under segregation? By prioritizing households' right to preserve and build the equity already present in neighborhoods of color, this Article joins the call to look beyond the paradigm of moving minorities out of their home jurisdictions and into white neighborhoods-the crossing-the-color-line narrative of the fair housing movement. ${ }^{147}$

The second prong of local government adequacy is habitability, a factor with aspects of both affirmative and negative rights. On the one hand, habitability means provision of services commensurate with local densities

146. See, e.g., FRUG, supra note 90; Briffault, supra note 90; Richard Thompson Ford, Beyond Borders: A Partial Response to Richard Briffault, 48 STAN. L. REV. 1173 (1996); Ford, supra note 90; Eduardo M. Peñalver, Property as Entrance, 91 VA. L. REV. 1889 (2005).

147. Several scholars of housing desegregation have issued this summons. See, e.g., Michelle Adams, Separate and [Un]Equal: Housing Choice, Mobility, and Equalization in the Federally Subsidized Housing Program, 71 TUL. L. REV. 413 (1996); John O. Calmore, Spatial Equality and the Kemer Commission Report: A Back-to-the-Future Essay, 71 N.C. L. REV. 1487 (1993). 
and local needs-specifically, services that ensure personal safety (including law enforcement, emergency services, and road infrastructure) and sanitation (including water and sewers). Habitability also means freedom from a disproportionate concentration of undesirable land uses, including the local air pollution, noise, and ground contamination these uses can cause if not properly regulated and monitored. Local governments' police powers to protect health, safety, and welfare provide the authority, and arguably the mandate, for stewardship on both of these fronts.

Habitability is deeply related to mobility, because neighborhood safety, sanitation, and comfort make one's existing property competitive on open housing markets. By giving homeowners the choice to sell, habitability also makes the choice not to sell a meaningful one. Yet habitability and housing choice are also in tension, because more rigorous building and land-use standards can lead to condemnation, redevelopment, increased property tax burdens (in states without property tax caps), and rent increases that can trigger housing displacement. ${ }^{148}$ Indeed, habitability initiatives have a troubled past, particularly in the evictions and condemnations of millions of low-income minority households as part of urban renewal and slum clearance programs conducted in the name of improving area physical conditions and housing standards. ${ }^{149}$ In addition, low habitability standards can enable housing choice by reducing the costs of purchasing land and building homes-that is, by facilitating entry. The tension between these two factors invites debate over the optimum levels of building and land-use regulation to

148. See Larson, supra note 14, at 235-38 (describing the need to balance health, safety, and environmental concerns against the risk that strict land-use regulations and building codes will reduce the supply of affordable housing and impose compliance burdens on low-income families). In a recent study of housing vulnerability among the rural poor in four states, the authors found that land-use regulations and the scarcity of affordable housing alternatives are core causes of financial insecurity and the risk of housing displacement. See, e.g., Katherine MacTavish et al., Housing Vulnerability Among Rural Trailer-Park Households, 13 GEO. J. ON POVERTY L. \& POL'Y 95, 98-110 (2006). For historical perspectives on the tension between habitability and the preservation of low-income communities, see WIESE, supra note 86, at 64-65, 104-09, and Moore, supra note 48 , at $99-100$.

149. Rich local histories of such programs are provided in such works as ARNOLD R. HIRSCH, MAKING THE SECOND GHETTO: RACE \& HOUSING IN CHICAGO 1940-1960, at 100-34 (1998), Raymond A. Mohl, Race and Space in the Modern City: Interstate-95 and the Black Community in Miami, in URBAN POLICY IN TWENTIETH-CENTURY AMERICA 100, 100-58 (Arnold R. Hirsch \& Raymond A. Mohl eds., 1993) (Miami, Florida), MOORE, supra nore 48, at 97-100 (Richmond, California), ROBERT O. SELF, AMERICAN BABYLON: RACE AND THE STRUGGLE FOR POSTWAR OAKLAND 139-55 (2003) (Oakland, California), and THOMAS J. SugRUE, THE ORIGINS OF THE URBAN CRISIS: RACE AND INEQUALITY IN POSTWAR DETROIT 48-50 (2005). 
ensure health and safety and property appreciation, on the one hand, and the ability to acquire and to retain land and housing, on the other. ${ }^{150}$

Finally, adequate local government must be measured in terms of the goal of political voice - the ability for citizens to engage in public decisionmaking processes that can meaningfully affect opportunity and material conditions in their neighborhoods. To affect such conditions, two dimensions of political voice are most salient. The first is the power to protest - the ability to resist undesirable land uses and other neighborhood harms. The second is advocacy-the ability to draw local resources, as well as private and intergovernmental investment, towards one's neighborhood. These twin tenets carry the pitfalls attendant to local democracy (such as NIMBYism and rentseeking), but in a fragmented, competitive jurisdictional marketplace where such pitfalls are endemic, a neighborhood with weak power to protest or advocate is vulnerable to regional inequity and neglect. ${ }^{151}$

Political voice is the underpinning of voting rights reforms, including redistricting, that seek not only to provide formal access to polls, but also to empower minority communities through robust and proximate political influence. Political theorists and local government scholars have long posited that the issue of scale is central to this endeavor, as participation in accessible, small-scale public decisionmaking is credited with enhancing individual engagement and empowerment through the exercise of control

150. Jane Larson and Richard Delgado have debated whether the absence of land-use control and building code enforcement in colonias development protects a vital source of affordable housing or perpetuates nonlivable wages and racial double standards by enabling substandard housing for low-income minority workers. Compare Larson, supra note 14, 238-39 (arguing for progressive compliance with improved building and service standards in colonias, rather than the adoption and enforcement of full-scale, traditional building and land use regulatory regimes), and Larson, supra note 26 , at 160-75 (defending a theory of progressive regularization in colonias), with Delgado, supra note 82, at 674-75, 688 (arguing that relaxed standards in building and land-use codes in colonias would reinforce the racial and socioeconomic hierarchy that created colonias from the first). In future work, I will more squarely engage this debate and its implications for regulatory interventions to address the service and infrastructure needs in unincorporated urban areas.

151. The tool of neighborhood-based advocacy and the outcome of equitable regional distribution of harms and advantages, however, need not and should not be in tension, as the criticisms of NIMBYism often assume. Scott Cummings has theorized that the value of local empowerment, a centerpiece of the community economic development movement, is best served by regionally focused advocacy rather than a narrowly local approach. See Scott L. Cummings, Recentralization: Community Economic Development and the Case for Regionalism, 8 J. SMALL \& EMERGING BUS. L. 131 (2004); see also id. (waming of the risk of "valor[ing] local action at the cost of de-emphasizing the critical importance of metropolitan coordination"). Nevertheless, whether the goal is local or regional change, political voice at the community or neighborhood level is a prerequisite for local empowerment. Both the allocation of public dollars and the concentration of dangerous, noisy, and polluting land uses are at stake in local government decisionmaking. See generally Robert D. Bullard, Neighborhoods "Zoned" for Garbage, in THE QUEST FOR ENVIRONMENTAL JUSTICE: HUMAN RIGHTS AND THE POLITICS OF POLLUTION 43, 43-61 (Robert D. Bullard ed., 2005). 
over one's own life and surroundings. ${ }^{152}$ In this sense, political voice and local democracy justify local government autonomy- "the ability of people within distinct small areas to decide for themselves by democratic means the matters that fall within the competence of local authority."153 By asking whether there is enough voice rather than enough government, this factor ensures that adequacy turns on democratic accountability and participation rather than the depth of municipal bureaucracy, as might an estimation of habitability alone. ${ }^{154}$

\section{B. Adequacy Applied: Single-Tier Local Government}

In unincorporated urban areas, urban life encounters rural public services and discordant land uses. Fast and frequent drivers roar along dirt roads with no sidewalks or drainage. Streets lack public lighting, enabling crime with impunity and the dumping of waste in alleys and empty lots. Front lawns crowd with motley configurations of propane tanks, water cisterns, and generators, while underground, tightly packed septic systems fail. Residential suburbs nestle against incinerators and international airport runways. Political participation requires travel to county seats that may be many miles, if not hours, away. Through the lens of the adequacy framework discussed above, this Part analyzes the compatibility of urban life with reliance on counties as the most proximate tier of general purpose local government.

152. See, e.g., FRUG, supra note 90 , at 23 .

153. Briffault, supra note 90 , at 1115 .

154. The formulation presented here offers an interesting opportunity for economists to consider local government optimization in terms of the balance between housing market mobility, habitability, and political participation. At what point does an additional layer of local government form (a special district, a municipality, etc.) support or hinder those three objectives? A model for this type of analysis is provided in Robert D. Cooter, The Optimal Number of Governments for Economic Development, in MARKET-AUGMENTING GOVERNMENT: THE INSTITUTIONAL FOUNDATIONS FOR PROSPERITY 297, 297-336 (Omar Azfar \& Charles A. Cadwell eds., 2006). 


\section{A Few Words About County Government ${ }^{155}$}

\section{Like municipalities, counties are a form of general purpose local} government. Yet in the literature of local government law, which emphasizes vertical contests for power between states and municipalities, and horizontal contests for land, wealth, and power between cities and incorporated suburbs, counties are rarely mentioned, and seldom, if ever, disaggregated from municipal governments in terms of their capacity to provide for urbanized populations. ${ }^{156}$ This is a significant omission, given that counties are the most proximate tier of government for millions of Americans, and, in rural and urban counties alike, county land-use approvals are major catalysts of urban sprawl.

The existing literature emphasizes two aspects of county government. First, nearly every state is divided into counties that serve as passive administrative subdivisions of state government. ${ }^{157}$ In this role, they carry out state functions like running elections; assessing, collecting, and distributing property taxes to local governments; operating highway and road networks; recording legal documents like deeds and marriages; and operating jails and courthouses. ${ }^{158}$ County borders also demarcate the bureaucratic zones for delivering federal government services (including tax, law enforcement, and social security functions) and state services (such as public assistance, hospitals, and vocational rehabilitation programs). ${ }^{159}$ In both capacities, county borders are endowed with a historically rooted permanence, and

155. A more developed exploration of the range of county governments operating in America today, along with the nature of the fiscal and political forces acting upon them, will be provided in my forthcoming article Regional Localism: American County Government, supra note 4 . In this Article and my future work on counties, the following wise words bear noting: "We have in the United States what is probably the greatest output and complexity of laws relating to the government of cities that the world has ever seen." McQuillin Mun. Corp. § 1.33 (3d ed. 1999). Similar diversity exists among county governments across the country, and the description and analysis provided here is not without its exceptions and caveats. In the longer conversation about county govemment, this Article constitutes merely an early remark.

156. Just as Richard Briffault once made the critical step of differentiating urban and suburban municipalities, this Article thus hopes to open a debate on differentiating municipalities and counties. See Richard Briffault, Our Localism: Part I-The Structure of Local Government Law, 90 COLUM. L. REV. 1, 4 (1990).

157. Richard Briffault has observed that the U.S. Supreme Court has alternately treated local governments as miniature representative democracies and as administrative subdivisions of the state. See Richard Briffault, Our Localism: Part II-Localism and Legal Theory, 90 COLUM. L. REV. 346 (1990). In the case of counties, the latter quality is always present in the day-to-day administration of county government. See Briffault, supra note 156, at 73 n.309. Counties' functions as proximate local democracies, however, is poorly understood, yet equally significant.

158. See Tanis J. Salant, Overview of County Governments, in FORMS OF LOCAL GOVERNMENT: A HANDBOOK ON CITY, COUNTY AND REGIONAL OPTIONS 95, 98 (Roger L. Kemp ed., 1999).

159. See HERBERT SYDNEY DUNCOMBE, MODERN COUNTY GOVERNMENT 132 (1977); Briffault, supra note 156 , at 73 n. 309 . 
we tend to view county territories, quite justifiability, as fixed and immovable-a stark contrast to municipalities, where acts of incorporation, annexation, deannexation, and consolidation enable territorial self-determination.

In the aftermath of the suburban explosion, a second identity has emerged on the ground and in the literature: counties as providers or brokers of urban services. ${ }^{160}$ Today, so-called urban counties, which govern large and highly urbanized metropolitan regions, serve as substantial regional providers of law enforcement, water, sewage, emergency, and other municipal services. In addition to providing such services to their unincorporated communities, these counties also commonly provide them by contract to incorporated suburbs, thus creating the economy of scale necessary for large-scale urban infrastructure. ${ }^{161}$ The emergence of this role reflects counties' increasing participation in facilitating suburban growth and providing urban services, a trend caused by the financial squeeze in many cities, county revenue interests in residential development, and the lack of any alternative government unit capable of providing these services to dense unincorporated areas. ${ }^{162}$

These roles are key components of county governments. Yet we know little about counties' additional roles. The first missing link is counties' function as representative democracies for both unincorporated and incorporated constituencies. This is the legacy of the U.S. Supreme Court's decision in Avery v. Midland County, ${ }^{163}$ which applied the one-person, one-vote

160. Counties may provide services directly through a department or agency subordinate to county government, or the state legislature or area residents may establish special districts to provide such services. See U.S. CENSUS BUREAU, supra note 17, at vii. Even in the case of independent special districts (i.e., those not subordinate to county government), a great deal of interaction and overlap between counties and special districts is common-county supervisors may sit on governing boards for area special districts and/or county staff members may be appointed as staff for such entities. Counties' role interacting with (and sometimes leading) an array of special districts and regionally based state agencies will be addressed in Anderson, Regional Localism: American County Government, supra note 4.

161. The "rash of municipal incorporations" in the second half of the twentieth century led many counties to enter the business of providing basic services on a model often referred to as the "Lakewood Plan" or "contract city" model, in which small, incorporated municipalities contract for their services from the county government rather than building their own infrastructure and service bureaucracies. See MILLER, supra note 129, at vii; see also Mark B. Feldman \& Everett L. Jossy, Note, The Urban County: A Study of New Approaches to Local Government in Metropolitan Areas, 73 HARV. L. REV. 526 (1960). For an interesting analysis of one highly urbanized county, Los Angeles County, see Gerald E. Frug, Is Secession From the City of Los Angeles a Good Idea?, 49 UCLA L. REV. $1783,1784-88$ (2002).

162. See DUNCOMBE, supra note 159, at 132; see also NATIONAL ASSOCIATION OF COUNTIES, COUNTY GOVERNMENT OVERVIEW 1, available at http:/www.naco.org/Content/NavigationMenu/ About_Counties/County_Government/CountyOverview.pdf (last visited May 15, 2008).

163. 390 U.S. 474 (1968). 
rule to county government. This rule gives municipal residents the same vote as unincorporated residents in county elections, which, as a practical matter, dilutes the political power of unincorporated neighborhoods when compared to populous municipalities.

In addition to this democratic function, counties have independent legal authority to exercise police powers over their unincorporated populations, positioning them to act like municipalities for their unincorporated populations. ${ }^{164}$ Yet can we assume that they do, in fact, function like municipalities? It stands to wonder whether counties' obligations and interests stemming from their other three roles-as state administrative subdivisions, as service providers seeking to recruit and satisfy suburban municipalities, and as representatives accountable to incorporated and unincorporated populations-affect the political economy of county governance. At the very least, counties are likely to behave differently than municipalities when it comes to providing the most proximate tier of general purpose local government for unincorporated areas.

Any debate about the differences between counties and municipalities therefore starts from the observation that county politicians usually serve three distinct types of constituencies: municipal voters and their elected leaders in major cities, municipal voters and their elected leaders in suburbs that purchase services from the county, and voters in unincorporated areas. Counties are thus simultaneously local and regional governments. ${ }^{165}$

The final starting point for understanding county governments is that their urbanized populations tend to be residual. In small and large metropolitan areas alike, counties serve as the general purpose local government for any areas left over after other county land has been folded into one or more municipalities. This results from a cherry-picking process,

164. Indeed, even though development on unincorporated land in most areas remains less regulated than development within municipal borders, counties have taken an increasingly proactive role in land-use control, building-code enforcement, and metropolitan infrastructure. This new role is a late twentieth-century development, as counties traditionally were not in the business of providing the urban services and regulatory structure required for higher density living, due to a lack of awareness of the environmental and social costs of unregulated, unlimited urban sprawl. See, e.g, ROME, supra note 131, at 229 (describing how despite cities' and counties' authority to regulate land use, until the 1970s, counties failed to use their land-use powers at all, while cities typically used this power simply to protect property values and encourage economic development); id. at 221-53 (describing the increasing regulation of land use and subdivisions across the country).

165. For a thoughtful exploration of the history and legal position of county government in California, as well as the potential to strengthen counties' existing regional functions, see Jared Eigerman, Califormia Counties: Second-Rate Localities or Ready-Made Regional Governments?, 26 HASTINGS CONST. L.Q. 621 (1999) (arguing that counties in California are well suited to address regional planning issues). 
by which municipalities annex commercial or residential land with a promising tax base (often exchanging the extension of discounted urban services for the landowner or developer's consent to annexation). Defensive incorporations also account for the residual nature of county land. With a caveat explored below that some unincorporated areas are higher income, it remains very common that unincorporated communities capable of sustaining municipal independence incorporate to resist a financially disadvantageous annexation to an existing municipality or to reject their county's taxes, regulations, or degree of democratic responsiveness. ${ }^{166}$ As discussed in Part I.B, it is routine for the line drawing attendant to these restructurings to exclude properties offering lower tax revenues or residents considered undesirable through the lens of racial prejudice. ${ }^{167}$

What does it mean for the remaining unincorporated land within an urban region to rely on county government as its only tier of general purpose local government? Is there any inherent disadvantage to having one tier of local government rather than two? At first glance, the answer to this question appears to be no. Many affluent subdivisions, not to mention some of the nation's most regal estates, can be found on unincorporated land near urban or suburban municipalities. ${ }^{168}$ For wealthier communities, unincorporated status may be desirable in terms of both property taxes and services. ${ }^{169}$ Property taxes within unincorporated areas tend to be lower than

166. The power to incorporate a municipality lies with local residents and landowners, and requirements for such a step are minimal. See, e.g., Briffault, supra note 156, at 74-75. The exception to this cherry-picking model of municipal growth are those middle- and upper-income unincorporated strongholds that have decided against municipal incorporation and that, under state law, are able to resist annexation by an adjacent municipality.

167. See id. at 76.

168. Rancho Sante Fe, San Diego County, California; Genesee, Jefferson County, Colorado; Barton Creek, Travis County, Texas; Gladwyne, Montgomery County, Pennsylvania; Pelican Bay, Collier County, Florida; and Great Falls, Fairfax County, Virginia: such unincorporated communities are emblematic of wealth and spatial prestige, and all are among the one hundred highest-income places with at least 1,000 residents. See Highest Income Places in the United States, http:/en.wikipedia.org/wiki/Highest-income_places_in_the_United_States (last visited Mar. 31, 2008).

169. While some middle- and upper-income communities may derive economic advantage from remaining unincorporated as described above, it is not because unincorporated areas are subsidized by residents of incorporated places within the county. A certain share of the property taxes of city residents does go to counties, but these taxes fund services provided to the entire county territory, incorporated and unincorporated alike-services such as regional road networks, library systems, countywide social service agencies, and county jails and courthouses. For instance, in California, a statewide average of 21 percent of city residents' property tax revenues are distributed to the city, 27 percent to the county, 45 percent to the state and schools, and 7 percent to special districts. Michael Coleman, A Primer on California City Finance, W. CITY MAG., March 2005, at 5, available at http://www.californiacityfinance.com/FinancePrimer05.pdf. Most counties have the legal authority to levy property taxes and other assessments on unincorporated area residents in order to pay for services. For example, in Miami-Dade County, the county's approximately 1.2 million 
in municipalities that fund diverse services for economically heterogeneous constituencies. County governments impose fewer regulations (including service standards for subdivisions) on development, which gives developers or landowners more choice about the range and intensity of services for their properties. At the time of initial development, landowners may not be required to install collective water and sewage systems, dedicate or fund land for park use, provide streetlights and sidewalks, or comply with other minimum standards typical of municipal codes. After development, higher-income households can improve services in their neighborhoods by purchasing them a la carte from the county or nearby municipality (through special assessment districts, for instance ${ }^{170}$ ) rather than paying for them through increased property taxes-an approach that offers both control and the perception of efficiency, because assessment districts provide direct returns in a payee's own neighborhood. Landowners can also choose to rely on private substitutes for services typically provided by local government. For spacious lots on unsullied land, septic systems and wells can be cost-effective, and conditions like irregular roads without sidewalks can add to the ambiance of rural living or country estates. Able to purchase the services they want and decline those they do not, these residents control their community's physical condition and environmental safety. Such areas have been the object of many of the nation's most vicious annexation battles, as cities seek to use annexation to expand their tax base against the resistance of residents and county governments. ${ }^{171}$

In a low-income community, however, beset by the messiness of higherdensity living on tighter household budgets, do the same advantages of one-tier local government attach? Seen through the lens of a local government

unincorporated area residents, the majority of whom live in dense urban areas, fall within an Unincorporated Municipal Services Area subject to a special tax for city services. Residents of incorporated cities within the county are not subject to this tax. See About Miami-Dade County, http://www.miamidade.gov/infocenter/about_miami-dade.asp (last visited Mar. 31, 2008); Miami-Dade County, Distribution of Property (Ad Valorem) Taxes, http://www.miamidade.gov/ taxcollector/property_tax_whereitgoes.asp (last visited Mar. 31, 2008).

170. Also known as direct benefit assessments, these charges are imposed on landowners-often at their specific request or subject to their approval-within a defined area to finance public improvements such as sidewalks, streetlights, paving, sewers, curbs and gutters, business improvement services, and fire and medical rescue services. See Ronald $\mathrm{H}$. Rosenberg, The Changing Culture of American Land Use Regulation: Paying for Growth With Impact Fees, 59 SMU L. REV. 177, 195 n.58 (2006).

171. See, e.g., StopNCAnnexation, http://www.stopncannexation.com (last visited May 12, 2008) (detailing a self-described "[g]rassroots [e]ffort to [e]nd [forced] [a]nnexation [a]buse in North Carolina" that disseminates information about annexation battles in the state); AnnexReform.com, http://www.annexreform.com (last visited May 12, 2008) (a citizen group website that collects information about current annexation conflicts in Indiana). See generally Reynolds, supra note 15 , at $248-49 \&$ n. 1 . 
adequacy framework, there are sound reasons to hypothesize that for both categories of unincorporated urban areas identified here-those lacking basic public services and those burdened by damaged land or undesirable land uses-county government may present special limitations.

\section{Mobility: The Right to Move, the Right to Stay}

For low-income residents of unincorporated urban areas, most of whom are low-income homeowners, mobility is hampered by two factors: the opportunity costs of selling a property before land has been regularized with services, brownfield abatement, or other investment that makes it comfortably habitable (functioning like a penalty for premature sale); and the absence of affordable housing alternatives, particularly affordable homeownership options that permit property owners to relocate without falling on the housing tenure ladder. The public choice hypothesis of free movement-that unincorporated urban area residents can simply move to improve their housing conditions and to discipline their local government-is thus strained by both prerequisites of housing mobility.

Residents of most unincorporated urban areas occupy land that would be worth considerably more if it were "regularized" or "consolidated" (that is, fitted with basic infrastructure, including flood control) and rid of past contaminants and other hazards. Indeed, a majority of the unincorporated urban areas studied for the present Article are nestled near lands of considerably higher value. For instance, the Jackson Hamlet neighborhood in Moore County is just down the lane from a lakeside resort, and Bret Harte in Stanislaus County shares its streets with middle class subdivisions. In these areas, which are characterized by inferior land quality, service provision, and public investment that dates back to de jure and de facto racial segregation, moving before conditions have improved incurs a major penalty. To sell means giving up the appreciation of one's land that would accrue if basic governmental promises came through-clear water flowing from taps, roads paved and lit, wastewater unseen, solid waste cleared, and perhaps, annexation and municipal voting rights. Such a move means foregoing an economic reward for tolerance of dire conditions, even though those conditions have a long racial history and have meant decades of lower costs for local agencies and their taxpayers. The opportunity costs of exit are difficult to estimate, but research on the unincorporated urban areas surrounding 
Mebane, North Carolina found that exclusion from city lines, with its associated service deprivations, caused a 20 percent devaluation of local homes. ${ }^{172}$

The penalties incurred for exit are arguably even higher-and the need for mobility expressed as the right to stay even stronger-in unincorporated urban areas, where land often preserves powerful noneconomic values of cultural affinity, connection to forbearers, the sense of accomplishment in building and owning one's own home, and personal pride in one's heritage as an elder community pioneer. ${ }^{173}$ In a neighborhood like Jackson Hamlet, mentioned above, such values are a powerful source of connection and shared identity among residents, many of whom trace their family roots to the small cluster of African American families that settled and developed the area in the early twentieth century. ${ }^{174}$ Other community members moved to the enclave more than forty years ago to obtain jobs in the adjacent city, and many built their own homes. ${ }^{175}$ Intergenerational patterns of possession like those in Jackson Hamlet are also typical of colonias communities, where many original settlers tenaciously work to keep their land within family hands. ${ }^{176}$ In such cases, moving represents an economic decision and more, and the potential for utilitarian gain may never outweigh a household's emotional connection to and financial dependence on its land. Local government stewardship of mobility in those cases, then, means reinforcing habitability and political voice to allow residents a meaningful choice whether to stay or to sell.

Mobility also requires that families leaving a jurisdiction must be able to afford something better. ${ }^{177}$ Dramatic shortages of affordable housing across the country constrain low-income mobility, particularly for households seeking to maintain their status as homeowners. ${ }^{178}$ Relocation, which is onerous enough in a major metropolitan area, is even more infeasible or

172. Specifically, the research demonstrated that for a property valued at $\$ 40,000$, the impact of exclusion from city lines reached $\$ 10,000$ to $\$ 11,000$ per acre. See U.N.C. Ctr. for Civil Rights, supra note 101 , at 17 .

173. See generally ALBERT O. HIRSCHMAN, EXIT, VOICE, AND LOYALTY: RESPONSES TO DECLINE IN FIRMS, ORGANIZATIONS, AND STATES 96 (1970) (similarly recognizing that the highest prices for exit are extracted from "traditional human groups" reflecting family and community).

174. See U.N.C. Ctr. for Civil Rights, supra note 101, at 3-4.

175. See id.

176. Interview with Juan Carolos Cancino, former staff member, California Rural Legal Assistance, in San Francisco, California (July 17, 2007).

177. For a more in-depth discussion of this challenge, see Anderson, supra note 3 (discussing the "price of entry" and the "price of residence" faced by low-income households seeking to move into incorporated municipalities).

178. See John J. Delaney, Addressing the Workforce Housing Crisis in Maryland and Throughout the Nation: Do Land Use Regulations That Preclude Reasonable Housing Opportunity Based Upon Income Violate the Individual Liberties Protected by State Constitutions?, 33 U. BALT. L. REV. 153 (2004). 
undesirable in a small urban area with few jurisdictional alternatives. Minimum lot or building sizes, amenity requirements, minimum dwelling costs, and other land-use regulations function to exclude lower-income buyers from many areas with the features that make unincorporated urban areas desirable, such as open space, family-friendly communities, and proximity to city jobs. ${ }^{179}$ Municipalities also block or hamper the development of low-income housing by establishing single-family residential zoning, prohibiting multifamily housing developments, prohibiting dwelling types (such as mobile homes), and setting bedroom or bathroom minimums. ${ }^{180}$ By alienating land that has not appreciated at a rate comparable to that of the local housing market and facing a constrained market for replacement housing, residents of unincorporated urban areas risk falling on the tenure ladder, taking the downward step from homeowner to renter that has fueled the century's pattern of black land loss and reinforced racial inequality in property ownership constructed by segregation. ${ }^{181}$ The possibility of a cost-free exit may represent a hollow obedience to logic over reality, however appealing it might be as a matter of economic assumptions.

Constraints on mobility in unincorporated urban areas are not relieved by displacement. Counties, working with municipalities adjacent to these communities, are often tempted to address the problems in unincorporated urban areas by using zoning and eminent domain powers to the benefit of alternative landowners (whether public, commercial, industrial, or higher-end residential) with an economic interest in land at the city fringe. Rather than buttressing the economic stability of current communities by infusing their

179. See Jon C. Dubin, From Junkyards to Gentrification: Explicating a Right to Protective Zoning in Low-Income Communities of Color, 77 MINN. L. REV. 739, 755 n.73 (1993); see also Lior Jacob Strahilevitz, Exclusionary Amenities in Residential Communities, 92 VA. L. REV. 437 (2006).

180. Dubin, supra note 179 , at 756 n.74. Some states and municipalities have adopted measures to incentivize or require the construction of limited affordable housing, such as linkage fees (which require contributions from housing developers for off-site, low-income housing construction) and inclusionary zoning measures (which require developers to designate a percentage of their residential projects to low- or moderate-income housing), but these programs have been unable to satisfy demand, particularly for the lowest-income groups. Theodore C. Taub, Exactions, Linkages; and Regulatory Takings: The Developer's Perspective, in EXACTIONS, IMPACT FEES AND DEDICATIONS: SHAPING LAND-USE DEVELOPMENT AND FUNDING INFRASTRUCTURE IN THE DOLAN ERA 132-41 (Robert H. Freilich \& David W. Bushek eds., 1995). See generally Andrew G. Dietderich, An Egalitarian's Market: The Economics of Inclusionary Zoning Reclaimed, 24 FORDHAM URB. L.J. 23 (1996).

181. See discussion supra Part I.B; see also Mitchell, supra note 141, at 557, 563; MICHAEL K. BROWN ET AL., WHITEWASHING RACE: THE MYTH OF A COLOR-BLIND SOCIETY 66-103 (2003); THOMAS M. SHAPIRO, THE HIDDEN COST OF BEING AFRICAN-AMERICAN: HOW WEALTH PERPETUATES INEQUALITY 4-9, 36-40, 47-56, 87-101, 107-114 (2004) (describing and quantifying the lasting effects of segregation and discrimination on the accumulation and intergenerational transfer of wealth and real property assets within the black community). 
neighborhoods with capital investments that support habitability, counties may target these areas for urban renewal, redevelopment programs, service deprivations, and condemnations that force or encourage displacement before existing landowners have seen the regularized value of their land. Rather than buttressing the economic stability of current communities by infusing their neighborhoods with capital investments that support habitability, counties may target these areas for urban renewal, redevelopment programs, service deprivations, and condemnations that force or encourage displacement before existing landowners have seen the regularized value of their land. ${ }^{182}$

Such was the story of Meacham Park, a former unincorporated urban area near St. Louis, Missouri. After a fierce battle over school desegregation, drastic service reductions following the low-income neighborhood's transition from a white to a black community, and refusals to annex the area, Meacham Park's adjacent municipality (an exclusive suburban municipality called Kirkwood) abruptly annexed the area, rezoned the land for commercial use, and deployed eminent domain powers to displace the African American community. A Wal-Mart moved in immediately. ${ }^{183}$ Cast in the narrative of deviant property ownership subtly ascribed to low-income homeowners and other residents of minority communities-a socially constructed story of material stagnation, dependency, and lax maintenance ${ }^{184}$ - exit and displacement were framed as solutions to the problems in an unincorporated urban area, when in fact, they represented the final culmination of the same historic patterns of discrimination and racial disadvantage imposed through segregation. Such displacement is antithetical to an assessment of mobility grounded in principles of fair housing and voting rights.

In sum, lower service standards and weak building regulations (a lower entry price) can make counties a provider of much-needed affordable

182. Such policies can be quite explicit. The 1971 General Plan for the County of Tulare, California, for instance, promulgated an official policy of starving low-income unincorporated neighborhoods of infrastructure improvements as a means to achieve their permanent elimination. The Plan stated:

Public commitments to communities with little or no authentic future should be carefully examined before final action is initiated. These non-viable communities would, as a consequence of withholding majority public facilities such as sewer and water systems, enter a process of long term, natural decline as residents depart for improved opportunities in nearby communities.

County of Tulare General Plan 2-1 (1971) (on file with author).

183. WIESE, supra note 86, at 247-48; Telephone Interview with Andrew Wiese, Professor of History, San Diego State University (July 17, 2007).

184. See Calmore, supra note 147; Mitchell, supra note 141. 
housing. Yet the same lack of regulation enables collective material conditions that burden property appreciation (a higher exit price). At first glance, this diagnosis might make counties appear both better and worse than municipal governments. But in an adequacy framework tethered to desegregating the privileges attached to land, the provision of substandard housing is not a meaningful offer of urban mobility. As long as land appreciation rates remain dramatically uneven in accordance with the lines drawn by racial segregation, the lack of public investment will burden the substantive mobility of homeowners who have battled for decades to hold on to their land and to improve their communities.

\section{Habitability: Safety, Services, and Clean Neighbors}

The two prongs of habitability-its affirmative aspects concerning services and infrastructure and its negative aspects in protection from an overconcentration of damaging neighbors-roughly correlate to the two types of unincorporated urban areas identified in this Article. Counties may fail an adequacy analysis on both fronts (as is the case for unincorporated urban areas outside Modesto), but for the purposes of discussion, these factors are treated separately in light of the specific category of unincorporated urban area most affected.

In the first category, a neighborhood seeking improved public services inevitably requires a surge of initial investment. In the case of unincorporated urban areas needing water and sewer systems, for instance, residents may well be willing and able to pay tie-in or user fees to a provider, ${ }^{185}$ but it is exceedingly rare that any community, rich or poor, can reach majority agreement to pay hundreds of thousands, often millions, of dollars to retrofit an existing community with an underground water or sewer system. Such retrofits-which involve, at a minimum, tearing up local streets and removing existing septic systems-are considerably more expensive than the cost of laying such lines on naked land. For that reason, it was through federal and state block grants that the country regularized (for example, installed underground urban services) the massive middle-class suburbs of the postwar period, many of which had been built on unregulated, unincorporated land

185. Once the groundwork for necessary collective infrastructure is built, unincorporated urban areas generally pay more than households within city limits to tie in and use that infrastructure. Unless a county or special district system is available to serve the unincorporated urban area, infrastructure built to serve these communities at a municipality's fringe generally ties in to that city's water and sewer network, and cities are empowered to charge a premium for services provided extraterritorially. 
and equipped with rudimentary infrastructure like septic systems. ${ }^{186}$ As a historic matter and still true today, federal, state, and municipal governments have heavily subsidized the infrastructure of middle-class and affluent suburbs through direct funding (such as intergovernmental grants for new sewage processing and collection facilities) and indirect support (such as mortgage assistance to homeowners that enabled them to afford home prices that reflected the costs of developer-installed infrastructure). ${ }^{187}$ Wealthier communities on larger lots may never face this dilemma, because sophisticated wells and larger lots with viable septic tanks can permit the unserved status quo. Housing density, lot sizes, soil types, and contamination hazards in the lower-income communities identified in the present study, by contrast, make the decision to do nothing a veritable health hazard. ${ }^{188}$

An unincorporated urban area seeking a new water or waste system faces a formidable challenge in convincing a county to commit to funding such infrastructure from its own coffers. Without exception, the areas lacking infrastructure identified in this Article (i.e., the first type of unincorporated area identified in Part I.A) lie in primarily rural counties beholden to the demands of nonresidential interests, such as agriculture or industry. As discussed in the next section, urbanized residential clusters within such

186. See generally ROME, supra note 131

187. See, e.g., RiCHARDSON DilWORTH, THE URban ORIGINS OF SUbURBAN AUTONOMY (2005); DAVID M. P. FREUND, COLORED PROPERTY: STATE POlICY AND WhITE RACIAL POLITICS IN SUBURBAN AMERICA 99-139 (2007); JACKSON, supra note 108, at 131; MARTIN V. MELOSI, THE SANITARY CITY: URBAN INFRASTRUCTURE IN AMERICA FROM COLONIAL TIMES TO THE PRESENT (2000); William L. Andreen, The Evolution of Water Pollution Control in the United States-State, Local, and Federal Efforts, 1789-1972: Part II, 22 STAN. ENV. L.J. 214, 226, 290 (2003); Nicole Stelle Garnett, Unsubsidizing Suburbia: The Urban Origins of Suburban Autonomy, 90 MINN. L. REV. 459 (2005) (reviewing DILWORTH, supra). Some portion of this subsidization occurred in the form of city financing of service extensions to newly annexed suburbs. In an economic analysis of the motives behind annexations during the 1950s, for instance, the author found that a large majority of the cities claiming an economic motive for annexations of suburban areas did not expect to obtain tax revenues covering the cost of new service extensions. See D. Andrew Austin, Politics vs. Economics: Evidence From Municipal Annexation, 45 J. URB. ECON. 501, 504 (1999). Instead of pursuing purely economic motives for annexation as was claimed, the study found that cities pursued political ends, including the use of annexation to increase the proportion of white voters and to dilute nonwhite voting power within the city. Id. at 528-29.

188. In the history of funding public services (discussed in greater detail in a forthcoming article), public entities, not individual households, traditionally bore the cost of equipping residential neighborhoods with infrastructure. City financing subsequently evolved towards a pay for what you get system of infrastructure financing, in which the costs of laying infrastructure beneath a new subdivision are borne by developers and passed on to homebuyers. See generally Laurie Reynolds, Taxes, Fees, Assessments, Dues, and the "Get What You Pay For" Model of Local Government, 56 FLA. L. REV. 373 (2004); Rosenberg, supra note 170. These costs, as noted, are much lower than infrastructure retrofit projects-a bitter pill for communities established without necessary initial infrastructure under conditions of racial discrimination and segregation. See Anderson, supra note 3. 
counties are likely to be ignored in county budgeting processes that favor minimizing costs and keeping county government small.

Personal safety, also a component of habitability, can be similarly undermined by the discordance between the needs of unincorporated urban areas and other county interests. In Kern, Fresno, and Stanislaus Counties in California, for instance, the county sheriffs' departments cover large swathes of agricultural land punctuated by isolated homes or small, high-value subdivisions, agricultural facilities, and industrial facilities like canneries and warehouses. Yet these sheriffs' departments also cover the unincorporated islands and urban fringes of these counties' burgeoning cities, where crime has become more urban in nature, with a growing presence of gangs and violence. Some residents believe that increasing concentrations of crime in their communities are related to the distance and neglect of county law enforcement and the foregone efficiencies of having these areas patrolled by city police, whose jurisdictional lines stop within yards of unincorporated urban areas that they must routinely traverse to travel between points on city land.

The second category of unincorporated urban areas-those with damaged land or land desired for industrial facilities or unsightly public uses-also experiences an inattentiveness to its needs and land values that seems peculiar to county rule. When undesirable (but perhaps lucrative) land-use proposals seek approval, county governments have weak political incentives and weak regulatory control to resist on behalf of the project's putative neighbors. Such scenarios arise in every urban area, ranging from a state agency, special district, or municipality's effort to site a public project (like a sewage plant, freeway, prison, or landfill) in relative proximity to the adjacent city, to an industrial or agribusiness entity's interest in siting a private facility near a labor base and commercial network. Counties' dependence on property taxes and sales taxes create powerful fiscal incentives to permit such development regardless of its burdens on neighbors. The same fiscal incentives also drive counties to accommodate land uses-such as public works, utilities, and freeways-that enable new tax-rich development elsewhere in the county. The weak voices of small low-income communities face a severe challenge to be heard among a county's larger economic interests.

An example of county acquiescence to regional planning needs and economic goals at the expense of unincorporated urban areas, East Los Angeles has been beset by land uses that have impaired the community's historical quest for independent incorporation. The City and County of Los Angeles and California state transportation agencies built no fewer than four freeway routes through the highly urbanized, unincorporated East Los 
Angeles area during the 1960 s, demolishing thousands of homes and fracturing dozens of diverse neighborhoods. ${ }^{189}$ The freeways, in the words of a local assemblyman at the time, "encircled, cut up, and gutted" the communities of East Los Angeles. ${ }^{190}$ They ravaged economic activity in the area through the displacement of local businesses and rendered the communities walled-off zones through which outsiders traveled without any contact, familiarity, or comfort. ${ }^{191}$ Without leverage against their overburdened, administratively complex, and distant county government, vociferous community opposition to the freeways failed to overcome the coalition interested in their construction: City of Los Angeles business interests sought suburban consumers and employees; the Los Angeles City Council sought to protect downtown economic activity; the County of Los Angeles stood to gain from the sprawl of new subdivisions promising additional county property taxes or contract municipalities to purchase county services; and the State Division of Highways envisioned the freeways as essential linkages in a polycentric, tri-county economic growth engine. ${ }^{192}$ Largely as a result of these freeways and other major streets, 26 percent of the land in East Los Angeles (compared with 17-22 percent in adjacent areas) is unparceled and not subject to taxation. ${ }^{193}$ These figures mean that today, despite East Los Angeles's large population and historic yearning for municipal autonomy, independent municipal incorporation may not prove fiscally desirable.

The risk that unincorporated urban areas will bear a disproportionate share of regional land-use burdens is compounded by the fact that many states have conferred extraterritorial powers on cities, an exception to the general rule that borders define the limits of local government authority. ${ }^{194}$

189. See, e.g., DiAZ, supra note 80 , at 53 . These routes destroyed some of the most racially diverse working-class communities of Los Angeles, with Jewish, Mexican, Italian, Japanese, and African Americans, which led to the resettlement of those groups in larger and more racially homogeneous areas. See AVILA, supra note 128, at 206-08.

190. See AVILA, supra note 128, at 212. Unincorporated East L.A. was not alone in bearing the brunt of the 5,10, and 710 freeways and Highway 60 . More than 10,000 residents of the Boyle Heights neighborhood, located within the City of Los Angeles, were displaced between 1946 and 1965 by construction of these same freeways, as well as a major interchange among them.

191. By creating sightless corridors in which suburban residents could imagine and fear but not see the communities on the other side of the concrete freeway walls, the freeways are also credited with amplifying the psychological polarization between black and Latino districts like East Los Angeles and nearby middle-class suburbs. See id. at 213.

192. See id. at 215-18.

193. See EAST L.A. RESIDENTS ASS'N REPORT, supra note 129, at 14-15.

194. Three of the states analyzed here confer a form of extraterritorial land-use and zoning authority on their municipalities. See N.C. GEN. STAT. \$ 160A-360 (2005) (granting municipalities the authority to exercise the same powers within a defined extraterritorial sphere as are exercised within corporate limits); CAL. GOVT. CODE $§ 56076$ (2007) (defining a city's sphere of influence 
Extraterritorial power can include the exercise of police powers (such as zoning) and/or proprietary authority to own and to construct public works and other city-owned facilities beyond city borders. ${ }^{195}$ State laws establish the territory in which these activities can take place, usually an "extraterritorial zoning jurisdiction" defined as all unincorporated land within a fixed distance from city lines. ${ }^{196}$ Cross-border authority may also include the power to exercise eminent domain outside city lines for the purpose of siting public uses such as utilities, waterworks, electric and gas plants, power lines, waste processing facilities, and public parks. ${ }^{197}$ From the perspective of growth control, extraterritorial authority wisely empowers cities to control their areas of future expansion and ensures that they will not be burdened with the effects of county planning decisions. From the perspective of political community, however, it also allows cities to regulate those whom they need not serve or enfranchise. ${ }^{198}$ Whatever the political disadvantages of these state systems, their legal permissibility is clear. ${ }^{199}$

as the area designated for a city's future growth and service extensions); CAL. GOVT. CODE § 65859 (permitting cities to prezone unincorporated areas within the city's sphere of influence to determine the zoning that will apply to that territory upon annexation); TEX. LOC. GOV'T CODE ANN. $\$ \$ 42.001-42.904$ (Vemon 2007) (establishing extraterritorial jurisdictions and the power of municipalities within those areas).

195. See, e.g., Sander M. Stevenson, 1-24 ANTIEAU ON LOCAL GOVERNMENT LAW § 24.08 (2d ed. 2003); see also Briffault, supra note 90, at 1131-32 (discussing the problematic nature of extraterritorial service provision and regulation).

196. See, e.g., N.C. GEN. STAT. § 160A-360 (granting municipalities the authority to exercise the same powers within a defined extraterritorial sphere as are exercised within corporate limits); ARIZ. REV. STAT. ANN. \$9-401(A) (2007) (granting power to purchase land extraterritorially and to enforce city code there); ARIZ. REV. STAT. ANN. \$9-461.11 (establishing a three-mile extraterritorial zoning jurisdiction); ARIZ, REV. STAT. ANN. §9-511(C) (2007) (establishing the right to site public utilities and other uses outside corporate limits); IND. CODE ANN. § 36-1-4-18 (granting municipalities the right to own, operate, and dispose of property within a four-mile radius outside the city's corporate boundaries); N.M. STAT. ANN. \$3-21-2 to 3-21-3 (2007) (granting smaller municipalities extraterritorial zoning jurisdiction).

197. See, e.g., ARIZ. REV. STAT. ANN. \& 9-511(A)-(C); UTAH CONST. art. XI § 5(b) (2007); GA. CODE ANN. \$ 36-82-62 (2007); OHIO CONST. art. XVIII, § 4; see also Vickery v. City of Carmel, 424 N.E.2d 147, 150 (Ind. Ct. App. 1981) (interpreting IND. CODE ANN. \$ 32-1 to grant eminent domain powers within cities' extraterritorial jurisdiction).

198. This tension and a U.S. Supreme Court case squarely confronting it are both analyzed infra Part III.B.4.

199. In Holt Civic Club v. City of Tuscaloosa, 439 U.S. 60 (1978), a neighborhood association and residents of Holt, an unincorporated community on the outskirts of Tuscaloosa, Alabama, challenged state "police jurisdiction" statutes by which their community had no voting rights in municipal elections but was subject to Tuscaloosa's police and sanitary regulations, the criminal jurisdiction of the city's court, and the city's business licensing rules. The Court rejected the unincorporated area's claim that the city's extraterritorial exercise of police powers over them, without a concomitant extension of the municipal franchise, denied Holt residents' due process and equal protection rights. Id. at $62-63,70$. One-person, one-vote principles, the Court held, had 
For the unincorporated urban areas in Moore County, North Carolina, extraterritorial zoning authority has meant that incorporated cities can lay their municipal sewage lines under streets traversing predominantly black unincorporated urban areas in order to reach newly annexed, predominantly white subdivisions, while barring residents along the way from tying their homes into the system. ${ }^{200}$ The unincorporated fringe communities of Alamance County, North Carolina similarly lament their disenfranchisement in the face of extraterritorial authority. In all but one section, a proposed interstate bypass is slated to traverse the city of Mebane's extraterritorial zoning jurisdiction while remaining a comfortable distance away from city borders, thus achieving city advantage without displacing city constituents or devaluing city land. ${ }^{201}$ Having survived for more than a century--a history captured in local buildings founded as early as 1864-the unincorporated urban areas are now fighting for their homes, land values, and quality of life. Residents of these communities, who have no voting rights within the decisionmaking city, must bring their opposition to the county, which itself has economic interests in spurring the development of revenue-generating subdivisions on county land. For the city, the new highways offer a dual win: they will stimulate the development of middle-class subdivisions attractive for future annexation to the city, while also eliminating a cross-section of the households that might allege that those annexations are racially regressive under the Voting Rights Act of $1965 .^{202}$

Even if single-tier government represents specific habitability challenges, the question remains: Is it any worse than similar perils attendant to two tiers of general purpose local government? Residence in an incorporated area cannot avert significant service deprivations in poor communities when it comes to law enforcement, fire, education, and the like. Yet the

never interfered with the longstanding rule that units of government could limit eligibility for the right to vote in local elections to persons residing within their borders. Id. at 68-69.

200. See U.N.C. Ctr. for Civil Rights, supra note 101.

201. Maps of the area, the proposed bypass, and the boundaries of municipal sewage services are available at the website of the West End Revitalization Association. See West End Revitalization Association, supra note 38; see also Johnson et al., supra note 38, at 93 fig.1, 94 fig.2, 99 fig. 3, 102 fig. 4 .

202. 42 U.S.C. $\$ \S 1973$ to 1973 bb-1 (2000). This type of claim is discussed in detail in a companion article. See Anderson, supra note 3. It is a similar story in Shaw Heights, a high-poverty black enclave pinned between the cities of Fort Bragg and Fayetteville that has "long been neglected" by the neighboring cities and Cumberland County. The area lacks sewer lines and has been passed over for annexation several times by Fayetteville. Yet local officials are currently considering running an interstate highway through the residential community, a move that is expected to stimulate enough redevelopment to lure Fayetteville into serving and annexing the community but will come at the cost of displacing many residents and businesses in Shaw Heights. See Bryan Mims, Bragg Growth, Highway to Lift Longtime Eyesore, WRAL.COM, June 6, 2007, http://wral.com/news/local/story/1478589. 
present study found that the nature of these challenges is affected by the presence or absence of municipal governments. Municipalities, as discussed, generally have much stronger code standards than counties when it comes to infrastructure and services. In addition, antidiscrimination law has greater potential to prevent the racially discriminatory distribution of such services where they are provided to residents as a feature of municipal citizenship. It is all but impossible to prevail on such claims against a county that does not provide those services cost-free to any residents, minority or not.

The environmental justice problem of overconcentrating undesirable land uses in disenfranchised communities is similarly not limited to counties. Municipalities, like counties, have incentives to load undesirable land uses on low-influence, low-income communities. Yet exposure to overconcentrations of undesirable uses is arguably higher in counties for at least three of the reasons discussed above: cities' extraterritorial authority and their tremendous incentive to externalize undesirable facilities or public works projects that benefit municipal populations; counties' looser land-use regulations, which can permit the juxtaposition of incompatible industrial and residential uses unlikely within municipal lines; and the challenges in asserting an effective political voice in county democracy, discussed below, which may impede the efficacy of neighborhood protest against specific projects.

\section{Political Voice: County Democracy}

In Holt Civic Club v. City of Tuscaloos $a,{ }^{203}$ which upheld a state law excluding unincorporated residents within a city's extraterritorial zoning jurisdiction from the municipal franchise despite their accountability to city regulation, the Supreme Court found that residents could (and should) seek political, as opposed to constitutional, correction for their woes. Chief Justice Rehnquist, writing for the Court majority, reasoned that the right to vote in state elections gave unincorporated area residents the opportunity to take their grievance to the legislature and advocate to alter their relationship to the city. ${ }^{204}$ Justice Stevens's concurring opinion noted that unincorporated area residents' right to vote in county, state, and federal elections gave them influence over the "officials who exercise primary control over their day-today lives."205 Both opinions thus presumed the option for political voice. Is

203. 439 U.S. 60 (1978).

204. See id. at 74 (Rehnquist, J.).

205. Id. at 77 (Stevens, J., concurring). 
this option as meaningful for unincorporated urban areas as it is for residents of their neighboring municipalities?

Residents of unincorporated urban areas may, of course, vote in county elections or in any election held by special districts to which they belong. However, both of these types of franchise are shared with residents of incorporated municipalities within the same county or special district. ${ }^{206}$ One or more of three barriers may impede the exercise of a robust vote at the tier of county government: a mismatch between the needs and norms of urban living and the norms of rural living and services; the dilution of the neighborhood's vote within a geographically dispersed and numerically oversized county government whose elected officials cater to both incorporated and unincorporated constituents; and city-county agreements that it would be to the economic advantage of both governments to phase out residential use of the unincorporated urban area. One or more of at least two barriers may impede the exercise of a robust vote at the tier of county government: a mismatch between the needs and norms of urban living and the norms of rural living and services and the dilution of the neighborhood's vote within a geographically dispersed and numerically oversized county government whose elected officials cater to both incorporated and unincorporated constituents.

The first of these, a mismatch between urban needs and a rural county government, is exemplified in the experience of the communities outside the City of Modesto, California. Thousands of Latinos in unincorporated urban areas rely on a Board of Supervisors that governs a county that is economically dependent on powerful agricultural interests and the economic engine of the City of Modesto. Perhaps it is an expression of the disempowerment of the unincorporated urban areas in this regional political equation that the city and county have located a widely disproportionate share of undesirable, property-depreciating services for city residents in the unincorporated urban neighborhoods. Modesto's sewage treatment plant, for instance, is ironically situated beside two such neighborhoods whose homes lack access to sewer lines; its reeking fumes remind these communities of their exclusion from the benefits but not the burdens of city sewage treatment. ${ }^{207}$ A neighboring

206. The catchments of special districts for schools, parks, water, sewage, or other services, do not necessarily conform to city or county boundaries.

207. Interview with Ina Lopez, No Man's Land resident, Stanislaus County, California (Sept. $14,2006)$ (on file with author); Interview with Maria Jaime, Attorney, California Rural Legal Assistance, Stanislaus County, California (Sept. 14, 2006) (on file with author). 
unincorporated urban area is home to the county's women's jail, men's jail, coroner's facility, and social services agency. ${ }^{208}$

The second common challenge to strengthening political voice in unincorporated urban areas is vote dilution: the weakening of a neighborhood's vote within the geographically and numerically larger county population, which includes both incorporated and unincorporated constituencies. As noted in Part III.B.1, the Fourteenth Amendment rule of one-person, one-vote applies to county governments, giving municipal residents the same vote as unincorporated area residents in county elections. ${ }^{209}$ In large, highly urbanized counties (exemplified by Alameda, Los Angeles, and Contra Costa Counties in California, each of which have unincorporated urban populations) that provide services by contract to dozens of suburban municipalities, county government can become a major bureaucracy, accountable foremost to suburban constituencies and other revenue-generating hubs. For instance, although Los Angeles County is home to only 1 million unincorporated residents compared to the 4 million residents of its largest municipality (the City of Los Angeles), those 1 million unincorporated county constituents share their voting rights for the Los Angeles Board of Supervisors with a total of more than $9,800,000$ county residents, and the county's unincorporated patches of land are scattered across an area that is more than 4,000 square miles. ${ }^{210}$ Such diffusion bodes poorly for unincorporated communities' individual or collective political voice.

Dilution can also erect spatial barriers to political participation. The unincorporated urban area of North Richmond, California, fọ instance, is less than five miles from City Hall in Richmond, but its residents must drive more than an hour to reach the county seat, which is located in a different city, to attend the meetings of their governing Board of Supervisors. ${ }^{211}$ Such a distance is no small barrier for low-income residents reliant on public transportation in a clogged metropolitan area. ${ }^{212}$ While cities can also be territorially expansive, counties are considerably larger on average, and they are often fragmented into diffuse, noncontiguous pockets of jurisdiction. In

208. Interview with Magdelena Mercado, supra note 58.

209. Avery v. Midland County, 390 U.S. 474, 479 (1968).

210. THE Federal ExeCuTIVE BD., LOS ANGELES, THE GREATER LOS ANGELES AREA IS GREATER THAN WE THINK 4 (2002), http://www.awp.faa.gov/new_feb/local_info.cfm.

211. See Telephone Interview with Jessie Slocum, sixty-five-year North Richmond resident (July 19, 2007) (on file with author).

212. To make it to one of the Board of Supervisors' monthly meetings, which are held at 9 a.m. on a weekday, a resident taking the bus must leave North Richmond at $7 \mathrm{a} . \mathrm{m}$. As a result much of the active community participation by North Richmond residents is directed at the City of Richmond, which must communicate and negotiate solutions with the County Board of Supervisors. Id. 
every state in the country, by contrast, municipalities are prohibited from noncontiguous growth, ${ }^{213}$ a rule no doubt underpinned by values of democratic access and service efficiency that should apply equally to populous unincorporated areas.

With respect to lobbying the state, unincorporated urban areas are severely constrained by their small size, diffuse geography, and economic weakness. Residents cannot lobby for annexation of their specific communities at the statewide level, because such legislation would constitute special legislation, (state legislation that targets a specific local government), which is prohibited or strictly limited in all but a handful of state constitutions. ${ }^{214}$ Instead, unincorporated urban areas must gain support for statewide reforms affecting all communities, which would face much more organized opposition from the lobbies of cities, counties, and wealthy unincorporated homeowners' associations that would oppose annexation and costly obligations to extend infrastructure. Political voice at the state level is not impossible of course, but it is a vastly more burdensome route to redress than organizing at the local level.

With respect to their adjacent municipalities, unincorporated urban areas have no voice at all, except insofar as they can pressure their counties to negotiate for services and annexation or mobilize opinion within the city. As a result, vote dilution occurs both inside and outside city borders, because large blocks of minority voters may be divided from one another. This dilutes both groups' influence over their respective local governments. Despite the fact that Latinos now represent 25 percent of the population of the City of Modesto, only one Latino has been elected to the at-large city council over the past one hundred years. Approximately 14,000 people live in the four unincorporated urban areas, ${ }^{215}$ and the political consequences of their exclusion could hardly be more stark: If these neighborhoods were annexed, the Latino population of Modesto would nearly double. Divided in that way, neither the inside voters nor the outside voters have the independent

213. See, e.g., N.C. GEN. STAT. $\$ 160$ A-36, -48 (2007).

214. See Briffault, supra note 156, at 9 n.18; Recent Case, Municipal Conporations-Legislative Control-Statute Applicable to a Single County Does Not Violate Constitutional Prohibition Against Special Legislation, 76 HARV. L. REV. 652, 652 (1963) (discussing Williams v. Rolfe, 114 N.W.2d 671 (Minn. 1962), and discussing state bars against special legislation). For instance, Indiana courts struck down a state legislative act prohibiting annexation of specific unincorporated neighborhoods on the fringes of South Bend, Indiana, whose wealthy residents were so opposed to annexation by the city (despite its promise of sewer and water systems) that they had lobbied for and won the attention of the state legislature. See Garnett, supra note 187, at 499.

215. See Lee Romney, Poor Neighborhoods Left Behind: Modesto Has Annexed Land for Upscale Tracts but Shunned Run-Doun Areas, Saying the County Should Improve Them. Suit Alleges Bias, L.A. TIMES, Sept. 18, 2005, at B6. 
political influence to assure equality in policy outputs, that is, to ensure that the unincorporated areas receive basic services. ${ }^{216}$

All avenues of political voice were not created equally. The structure of governance of unincorporated urban areas may diminish the ability of residents to protect their land and address community needs.

\section{CONCLUSION}

Urban life placed outside the reach of municipal government thus reveals itself as a condition that can constrain household mobility, enable the continuation of severe service deficiencies, heighten exposure to undesirable land uses, and inhibit participatory voice for low-income communities. When we leave conditions associated with city life--including housing density, poverty, and crime--within the jurisdiction of an underfunded, weak, or distant local government, we leave low-income residents to bear costs that, in other contexts, a greater collective would assume.

While voting rights and inclusion within municipalities do not represent a panacea of individual political voice and governmental responsiveness, unincorporated urban areas call us to look seriously at means for promoting annexation and inclusion. They call for state legal reforms that increase territorial outsiders' ability to initiate annexation, as well as legal reforms that create incentives for municipalities to annex low-income unincorporated areas. Where annexation is unavailable or undesirable, the unincorporated urban areas issue encourages changes to counties' resources, institutional structures, and regulatory regimes that improve county stewardship of urban life. Such reforms include enhancing county institutional capacity (and corresponding accountability) to compete for infrastructure investment in their urban areas, as well as the application of more rigorous land-use and health and safety standards in counties' urbanized areas. And finally, the history of the unincorporated urban areas and their intractability in the local political economy provide a normative basis for considering minimum service standards and augmenting funds for infrastructure investment in low-income counties. ${ }^{217}$ Such efforts would not amount to a claim to

216. Briffault has observed that extension of city borders to encompass people adversely affected by extraterritorial regulation is problematic because it produces a larger government unit, which is in tension with participatory values. He is correct from the perspective of existing municipal residents if the race of excluded voters is not taken into account, but the observation elides the participatory claims of the affected outsiders. See Briffault, supra note 90.

217. Mapped Out of Local Democracy, a forthcoming article, explores each of these three categories of reform. See Anderson, supra note 3. 
formal equalization of property values, but a claim to equal public inputs to support property appreciation in those neighborhoods passed by during earlier waves of public largess.

When we look towards the low-income city periphery, a new landscape for urban law comes into focus. Far from the government dependence at the center of inner-city narratives, we find government abdication and local selfreliance. We shift from questions of police brutality to police neglect; from tenants' rights to the insecurities of loans for low-income homeowners. We find exclusion through annexation, land loss through extraterritorial eminent domain, and misfit pairings of community need and government capacity. And perhaps most importantly, we encounter communities that have acquired neither mobility, habitability, nor political voice from the end of de jure residential segregation. Development of these alternative understandings of local government law are relevant beyond unincorporated urban areas, affecting the struggling first-ring suburban municipalities of the Midwest and the Northeast, as well as the small incorporated towns now teetering on the brink of economic collapse throughout the South. In the twenty-first century's story of urban change, all of these local governments may knock at the doors of other municipalities or counties for consolidation or dissolution. Deepening our understanding of county government is a first and necessary step in confronting the expansion of poverty beyond central cities. 